US Army Corps

of Engineers ${ }_{\circledast}$

Engineer Research and

Development Center

\title{
Degrading Permafrost Mapped with Electrical Resistivity Tomography, Airborne Imagery and LiDAR, and Seasonal Thaw Measurements
}

Thomas A. Douglas, M. Torre Jorgenson, Dana R. N. Brown, July 2021

Seth W. Campbell, Christopher A. Hiemstra,

Stephanie P. Saari, Kevin Bjella, and Anna K. Liljedahl 
The U.S. Army Engineer Research and Development Center (ERDC) solves the nation's toughest engineering and environmental challenges. ERDC develops innovative solutions in civil and military engineering, geospatial sciences, water resources, and environmental sciences for the Army, the Department of Defense, civilian agencies, and our nation's public good. Find out more at www.erdc.usace.army.mil.

To search for other technical reports published by ERDC, visit the ERDC online library at https://erdclibrary.on.worldcat.org/discovery. 


\section{Degrading Permafrost Mapped with Electrical Resistivity Tomography, Airborne Imagery and LiDAR, and Seasonal Thaw Measurements}

Thomas A. Douglas, Christopher A. Hiemstra, Stephanie P. Saari, Kevin Bjella

Cold Regions Research and Engineering Laboratory

U.S. Army Engineer Research and Development Center

Fort Wainwright, AK

Seth W. Campbell

Cold Regions Research and Engineering Laboratory

U.S. Army Engineer Research and Development Center

72 Lyme Road

Hanover, NH 07355

$\begin{array}{ll}\text { M. Torre Jorgenson } & \text { Dana R. N. Brown } \\ \text { Alaska Ecoscience } & \text { University of Alaska Fairbanks } \\ \text { Fairbanks, AK } & \text { Institute of Arctic Biology } \\ & \text { Dept of Biology \& Wildlife } \\ & \text { Fairbanks, AK }\end{array}$

Anna K. Liljedahl

University of Alaska Fairbanks

Water \& Environmental Research Ctr International Artic Research Center

Fairbanks, $A K$

Final report

Approved for public release; distribution is unlimited.

Prepared for U.S. Army Corps of Engineers

Washington, DC 20314

Under SERDP Project Number RC-2110, MIPR W W74RDV10209988 


\section{Preface}

This project was supported by funding from the U.S. Army Corps of Engineers, Engineer Research and Development Center's (ERDC) Center Directed Research and Basic Research Programs and the Department of Defense's Strategic Environmental Research and Development Program's (SERDP) Resource Conservation and Climate Change Program, Project RC-2110, MIPR W74RDV10209988.

The work was performed by the Biogeochemical Sciences Branch (Dr. Justin Berman, Chief) of the Research and Engineering Division (Mr. Jimmy Horne, Chief), U.S. Army Engineer Research and Development Center, Cold Regions Research Engineering Laboratory (ERDC-CRREL). At the time of publication, the Deputy Director for ERDC-CRREL was Mr. David Ringelberg and the Director was Dr. Joseph Corriveau.

This paper was originally published in Geophysics (online) 17 December 2015.

We thank A. Barker, M. Berkeland, K. Bjella, H. Genet, T. Gatesman, A. Gelvin, S. Hayes, M. Jones, K. Jorgenson, M. Lara, H. Lotvonen, K. Nicolato, and A. Wagner for their help with field measurements. Two anonymous reviewers provided constructive comments that strengthened an earlier version of the manuscript.

The Commander of ERDC was COL Teresa A. Schlosser and the Director was Dr. David W. Pittman.

DISCLAIMER: The contents of this report are not to be used for advertising, publication, or promotional purposes. Citation of trade names does not constitute an official endorsement or approval of the use of such commercial products. All product names and trademarks cited are the property of their respective owners. The findings of this report are not to be construed as an official Department of the Army position unless so designated by other authorized documents. 


\section{Degrading permafrost mapped with electrical resistivity tomography, airborne imagery and LiDAR, and seasonal thaw measurements}

\begin{abstract}
Accurate identification of the relationships between permafrost extent and landscape patterns can help to develop airborne geophysical or remote sensing tools to map permafrost in remote locations or across large areas. These tools will be particularly applicable in discontinuous permafrost where climate warming or disturbances such as human development or fire can lead to rapid permafrost degradation. We have linked field-based geophysical, point-scale, and imagery surveying measurements to map permafrost at five fire scars (1930, 1975, 1988, 2001, and 2010) on the Tanana Flats in central Alaska. Ground-based elevation surveys, seasonal thaw-depth profiles, and electrical resistivity tomography (ERT) measurements were combined with airborne imagery and light detection and ranging (LiDAR) to identify relationships between perma-
\end{abstract}

frost geomorphology and elapsed time since fire disturbance. ERT proved to be a robust technique for mapping the presence or absence of permafrost because of the marked difference in resistivity values for frozen versus unfrozen material. There was no clear relationship between elapsed time since fire and permafrost extent at our sites. However, we have found that the transition zone boundaries between permafrost soils and unfrozen soils in the collapse-scar bogs at our sites had complex and unpredictable morphologies. This result suggested that attempts to quantify the presence or absence of permafrost using aerial measurements alone could lead to incomplete results. Taken in total, the results from our study indicated that although ground-based ERT measurements were the most rapid means of mapping permafrost, we were still limited in being able to apply airborne surveying measurements at the landscape scale toward accurately estimating permafrost extent.

\section{INTRODUCTION}

Climate warming is expected to have pronounced effects on highlatitude ecosystems, particularly in discontinuous permafrost terrain, such as interior Alaska (Racine and Walters, 1994; Jorgenson et al., 2001, 2013; Osterkamp, 2007; Osterkamp et al., 2009). Future climate scenarios project an approximately $5^{\circ} \mathrm{C}$ increase in mean annual air temperatures in this region over the next 80 years (Chapman and Walsh, 2007), and this is expected to cause wide- spread permafrost degradation (Marchenko et al., 2008). The loss of permafrost can dramatically affect ecosystems by shifting vegetation (Potter, 2004; Walker et al., 2006; Wolken et al., 2011) and altering soil and hydrogeologic processes (Tarnocai and Campbell, 2002; Davidson and Janssens, 2006; Allison and Treseder, 2011; Johnson et al., 2011; Sierra et al., 2011; Douglas et al., 2013). There is great concern that permafrost thawing will yield increased carbon emissions from arctic and subarctic landscapes and provide a positive feedback to climate warming (Frey and Smith, 2005; McGuire 
et al., 2009; Koven et al., 2011; Schuur et al., 2013). Disturbance, such as wildfire or infrastructure development, can increase the ground heat flux and promote rapid permafrost thaw in ensuing years (Mann et al., 1995; Douglas et al., 2008, 2014; Kasischke et al., 2010). As a consequence, efforts to site and design infrastructure in permafrost terrains can be supported with information on the location of frozen ground in the subsurface.

Permafrost is defined as any earth material remaining below $0^{\circ} \mathrm{C}$ for more than two consecutive years. The spatial distribution of permafrost is controlled by the local soil thermal regime, which is influenced by air temperature, winter snowfall, topography, slope, aspect, hydrology, ground ice content, soil texture, plant cover, and fire history (Osterkamp and Romanovsky, 1999; Jorgenson and Osterkamp, 2005; Myers-Smith et al., 2008). In interior Alaska, permafrost is commonly found in areas where there is stunted vegetation and thick organic soils, which is consistent with the concept of "ecosystem-driven permafrost" identified by Shur and Jorgenson (2007). Any disturbance that leads to the removal of this insulating surface soil and vegetation layer (i.e., wildfire, infrastructure development, and changes in vegetation stability) can increase the ground heat flux and promote permafrost thaw (Viereck et al., 1973; Yoshikawa et al., 2003; Nossov et al., 2013). Surface water also increases energy gains and can cause a strong positive feedback to permafrost degradation (Jorgenson et al., 2010). Thawing of ice-rich permafrost can result in settlement and water impoundment. Interactions among fire, ground ice, and hydrology may, therefore, accelerate permafrost degradation and ecosystem change (Brown et al., 2015).

Fire is the greatest cause of disturbance in the boreal biome (Viereck, 1973; Zoltai et al., 1998; Kasischke et al., 2000a, 2000b; Wurtz et al., 2006; Barrett et al., 2011). Fires are growing larger, more intense, and more frequent in interior Alaska as a result of climate warming (Kasischke and Turetsky, 2006; Kasischke et al., 2010). The last decade had double the number of fires of any decade within the previous 40 years (Kasischke et al., 2010), a trend expected to continue with warmer and longer growing seasons (Duffy et al., 2005; Chapin et al., 2008; Balshi et al., 2009). Today, humans cause most fires but lightning-caused fires consume more land area (Douglas et al., 2014). Over the period from 1947 to 2011, larger fires have occurred predominantly on lowland terrains, and the period from 2001 to 2011 experienced the largest area burned of any decade (Wendler et al., 2011). These larger, more severe fires are associated with deeper burn depths, greater destruction of surface soils, and enhanced permafrost degradation (O'Neill et al., 2002, 2003; Zhuang et al., 2003).

Discontinuous permafrost in interior Alaska is widespread in lowlands and on north-facing slopes and is typically tens of meters thick (Racine and Walters, 1994; Chacho et al., 1995; Jorgenson et al., 2008; Douglas et al., 2011). On the Tanana Flats, where permafrost is strongly associated with abandoned floodplain deposits with peat-rich, silty soils, approximately $50 \%$ of the area is in some stage of permafrost degradation (Jorgenson et al., 1999). Permafrost stability is intricately coupled with ground ice abundance, the soil thermal regime, vegetation succession, terrain physiography, and disturbance. As a consequence, there is a need to correlate the response of permafrost to disturbance over space and time. Of principal concern are transition zones where frozen and thawed material meet. This is where the effects of permafrost thawing will be most pronounced, because as the thaw front moves into previously frozen material, subsidence, and changes in hydro- geology, soil, and vegetation can be initiated. Identifying and predicting the response of permafrost to warming or disturbance requires accurate and detailed assessment of subsurface characteristics, predominantly permafrost extent. Where permafrost presence (or absence) can be linked to surface biophysical characteristics that can be measured remotely, standoff detection tools could be developed toward mapping permafrost over large regions.

Geophysical techniques, particularly electric resistivity tomography (ERT), have been used to map subsurface permafrost and to link terrain geomorphology to permafrost ice content (Lawson et al., 1996; Yoshikawa et al., 2006; Douglas et al., 2008; Lewkowicz et al., 2011; Hubbard et al., 2013; McClymont et al., 2013; Kneisel et al., 2014). Airborne electromagnetic (AEM) measurements have been used to map permafrost over large spatial extents (Minsley et al., 2012), but its broad application has been limited due to the high acquisition costs. AEM is an excellent technique for identifying the vertical thickness of permafrost bodies, but it has limited utility in producing high-resolution information on the upper 1-5 m of the soil column where surface and shallow subsurface hydrogeology processes are focused.

ERT works well in permafrost terrains because the electric resistivity (in $\Omega \mathrm{m}$ ) of an earth material (rock, unfrozen soil, or frozen soil) is controlled by the mineralogy, porosity, moisture content, cation and anion concentration of pore moisture, temperature, and whether pore waters are frozen or thawed (Hauck and Kneisel, 2008). Resistivity $\rho$ values of frozen soils are generally $10-1000$ times greater than those of unfrozen or brine-rich soils (Harada and Yoshikawa, 1996). When combined with standoff topographic information such as aerial imagery and light detection and ranging (LiDAR) data, ERT has been used to link permafrost distribution with terrain geomorphologic and cryospheric properties (Lewkowicz et al., 2011; Hubbard et al., 2013).

This study mapped permafrost distribution using ERT and thawdepth probing, and it assessed the relationships between vegetation, differential global positioning system (dGPS) measurements, aerial imagery, and airborne-LiDAR derived topography. We focused our efforts at five locations in the Tanana Flats Lowlands south of Fairbanks that provided a chronosequence of fire histories ranging from 1930 to 2010. Specific objectives of the research were to (1) document changes in vegetation, topography, thaw depths, and ERT across the five fire scar sites of varying age; (2) quantify permafrost distribution with depth using thaw probing and ERT; and (3) evaluate relationships among biophysical factors to assess their effectiveness for mapping permafrost distribution. A companion study (Brown et al., 2015) focuses on the impacts of fire on permafrost stability, thermal modeling, and detailed soil and vegetation characteristics at the same sites.

\section{METHODS}

\section{Study area}

The approximately $8000 \mathrm{~km}^{2}$ Tanana Flats Lowlands is dominated by a combination of gravelly alluvial deposits extending northward from the northern slopes of the Alaska Range and abandoned floodplain deposits associated with the braided Tanana River (Walters et al., 1998; Jorgenson et al., 1999). The topography has extremely low elevational gradients (approximately $1 \mathrm{~m} / \mathrm{km}$ ). Hydrology is affected by channelized surface flow in small streams, some surface and shallow subsurface flow across fen systems, 
and by areas with substantial groundwater discharge (Racine and Walters, 1994). The Tanana River, the largest tributary of the Yukon River, is a major physiographic barrier forming the boundary around the northern portion of the Tanana Flats Lowlands.

Vegetation in the Tanana Flats Lowlands is a highly interspersed mixture of forest, scrub, bog, fen, and open water bodies (Jorgenson et al., 1999, 2001; Douglas et al., 2014). Forested regions are generally located on permafrost plateaus, whereas bogs and fens tend to be located in low-lying areas that commonly form in thermokarst depressions. Collapse-scar bogs, circular depressions generally hundreds of years old, dot the lowland terrain of Tanana Flats. They grow laterally and expand over time, so generally the larger bogs are the oldest (Jorgenson et al., 2001). Myers-Smith et al. (2008) find that fire-initiated permafrost thaw lead to an increase in rates of lateral expansion of collapse-scar bogs. Long, linear fens with floating vegetation mats are associated with groundwater discharge and are generally permafrost free (Racine and Walters, 1994; Racine et al., 1998). The collapse-scar bogs and nearby fens are bordered by forests growing above permafrost or perched above well-drained sand and gravels. Sphagnum bogs are common in round thermokarst depressions within the forest patches, and they are isolated from regional groundwater movement. The variable forest stands that cover the Tanana Flats Lowlands reflect differences in time since fire, permafrost extent, soil composition, and flood frequency (Jorgenson et al., 1999).

Bodies of discontinuous permafrost in the Tanana Flats Lowlands usually range from 0.5 to $12 \mathrm{~m}$ in vertical thickness (Racine and Walters, 1994), but sections up to $47 \mathrm{~m}$ thick have been documented (Chacho et al., 1995). Permafrost is abundant in areas with peat-rich fine-grained soils. Volumetric ice contents in birch and black spruce forests can reach greater than 50\% (Osterkamp et al., 2000; Jorgenson et al., 2001; Brown et al., 2015). Collapse-scar bogs are common in lowland black spruce forest regions. Where ice contents are typically closer to $20 \%$. Where present, ice-rich and ice-poor permafrost gelisols are predominately composed of gravel, silt, and sand (Pergelic Cryochrepts) overlaid by organic material (Pergelic Cryofibrists and Histic Pergelic Cryofibrists; Brabets et al., 2000). In a 1990s study in the northern portion of Tanana Flats, $17 \%$ of the area was unfrozen, $48 \%$ had stable permafrost, $31 \%$ was partially degraded, and $4 \%$ was totally degraded (Jorgenson et al., 1999). The permafrost in this area of the boreal biome is considered relatively "warm" (mean annual temperatures of $0^{\circ} \mathrm{C}$ to $-3^{\circ} \mathrm{C}$ ), which makes it particularly sensitive to the effects of climate change (Jorgenson et al., 2001).

The climate in interior Alaska is continental with a mean annual air temperature of $-3.3^{\circ} \mathrm{C}$, typical mean summer temperatures of $20^{\circ} \mathrm{C}$, and mean winter temperatures of $-20^{\circ} \mathrm{C}$. Yearly extremes range from $38^{\circ} \mathrm{C}$ to $-51^{\circ} \mathrm{C}$ (Jorgenson et al., 2001). The mean annual precipitation is $28 \mathrm{~cm}$ (Wendler and Shulski, 2009), with a typical annual snowfall of $1.7 \mathrm{~m}$ (Jorgenson et al., 2001). The snow pack represents $40 \%-45 \%$ of the mean annual precipitation (Liston and Hiemstra, 2011).

\section{Field measurements}

This study was designed to assess biophysical and permafrost characteristics across a chronosequence of time since wildfire. Our field sites are composed of five 200- to 300-m-long transects located in the northern third of the Tanana Flats Lowlands south of Fairbanks, Alaska (Figure 1). Fire years were ascertained from treering dating, airphoto and satellite imagery interpretation, and fireperimeter maps from the Alaska Interagency Coordination Center.

The five remote sites were accessed by helicopter between 2011 and 2014. In 2011, the transect end points were surveyed, and 1-mwide trails were cleared of large woody vegetation to facilitate access for surveying and geophysical measurements. A summary of the location, transect length, and maximum and minimum elevations at each site is provided in Table 1. Maximum seasonal thaw depths were determined at 1- to 5-m intervals along each transect at the end of summer (late August to early October) from 2011 to 2014. We used a 1-cm-diameter graduated metal rod ("frost probe") that extended to as much as $2.5 \mathrm{~m}$ in length. For each thaw-depth measurement, the frost probe was pushed vertically into the ground till refusal to establish the distance between the ground surface and the ice-bonded base of the active layer/top of the permafrost (Shiklomonov et al., 2013). If contact with permafrost was not made, the maximum observed depth of soft, unfrozen soil was recorded. In 2012, we made dGPS measurements at 1-m intervals along each transect to accurately survey the elevation, northing, and easting within $1.9 \mathrm{~cm}$ horizontally and $2.9 \mathrm{~cm}$ vertically. Ground-surface elevations were also determined using differential leveling.

Detailed information on the vegetation, soils, geomorphological characteristics, and permafrost composition are provided in Brown et al. (2015). The 2012 thaw-depth measurements are presented here because they correspond with the same time the ERT surveys

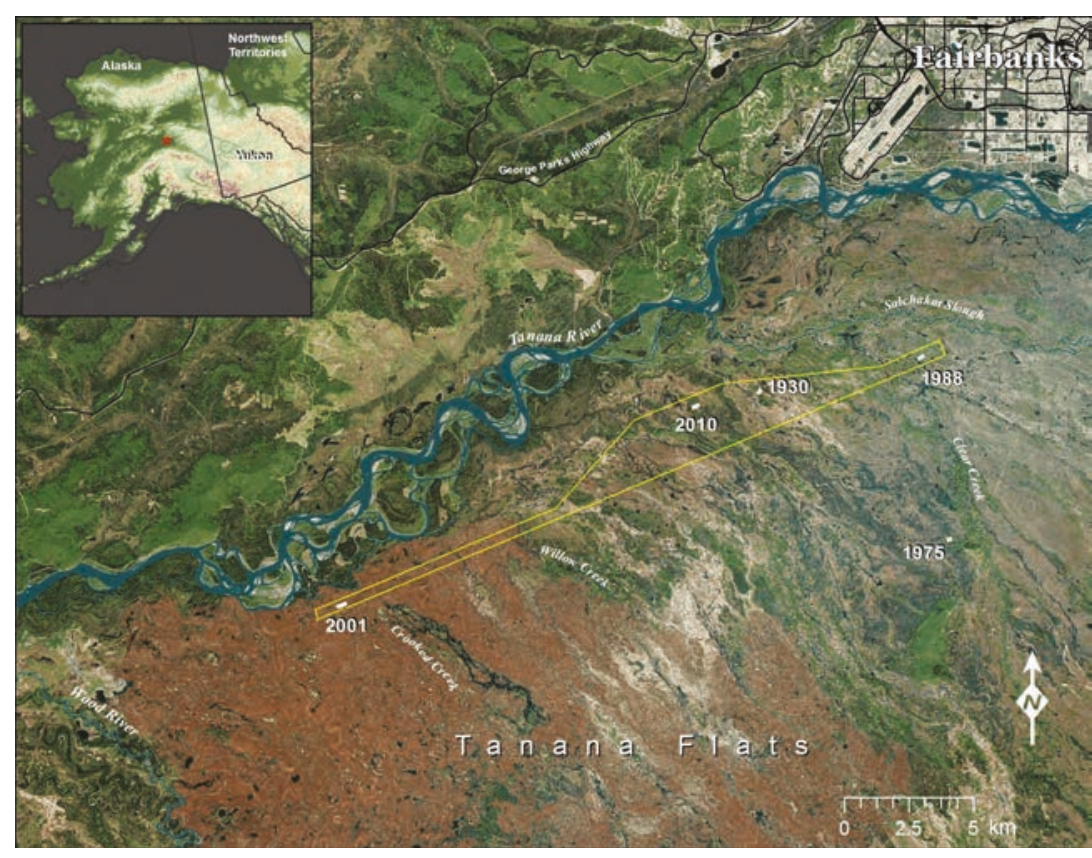

Figure 1. An aerial image of the northwestern portion of the Tanana Flats lowland near Fairbanks, Alaska. Locations of the five field sites are identified by the year of the fire that created the fire scar. The yellow line denotes the region within which airborne LiDAR was acquired in May 2014. 
were performed. Some additional thaw-depth measurements for 2013 or 2014, particularly maximum observed unfrozen depths, are provided for some sites to provide supporting data for surface zones lacking near-surface permafrost (NSP).

We used an 8-cm-diameter CRREL/Snow, Ice, and Permafrost Research Establishment (SIPRE) corer to extract 3- to 4-m-long cores from multiple locations along each transect. Detailed cryostructural and stratigraphic information are provided in Brown et al. (2015), but our main focus for the core information here is to support whether permafrost is present or absent along the transects.

Vegetation types along segments of the transects were assigned ecotypes using the classification developed for the area by Jorgenson et al. (1999). We modified the system, however, by just using the vegetation terms (e.g., broad-leaf forest), and we dropped the physiography and moisture modifiers used in the ecotype terminology to simplify the analysis and presentation. In addition, we split the bogs into early- (sedge-sphagnum bog meadow) and late-successional (dwarf shrub-sphagnum bog) vegetation types to better differentiate young thawing margins from older bog centers.

\section{Satellite and LiDAR imagery}

Recent high-resolution satellite imagery was obtained for all of the sites. Images were selected based on their clarity and lack of cloud cover. All of the imagery used consisted of multispectral imagery (usually 2- to 4-m resolution) and a companion panchromatic image (approximately 0.5-0.6 m). Using Erdas IMAGINE 2013, images were orthorectified, then pan sharpened with the hyperspherical color space resolution merge to yield submeter detail. The 1930 and 2001 burn sites were collected by Geoeye1 on 5 May 2011. The 1975 and 1988 burn sites were obtained by WorldView-2 on 21 May 2010. The 2010 burn site image was collected on 21 May 2010 (before the site was burned).

Airborne LiDAR imagery was collected from the 1930, 1988, 2001, and 2010 fire scars on 9-11 May 2014 by Quantum Spatial Incorporated (Anchorage, Alaska). A Leica (Wetzlar, Germany) ALS70 system (1064 nm) mounted in a Partenavia aircraft was used to acquire the imagery at an average pulse density of $\geq 25$ pulses $/ \mathrm{m}^{2}$ at an altitude of $1000 \mathrm{~m}$. The position of the aircraft was measured twice per second $(2 \mathrm{~Hz})$ by an onboard dGPS unit, and the aircraft attitude was measured at $200 \mathrm{~Hz}$ as pitch, roll, and yaw (heading) from an onboard inertial measurement unit. To allow for postprocessing correction and calibration, the aircraft and sensor positions and attitude data were indexed by GPS time. The measurement accuracy yielded an rms error of $\leq 9.2 \mathrm{~cm}$ and yielded a spatial resolution of $0.25 \mathrm{~m}$. The digital elevation model created from the LiDAR was hydroflattened to correct for streams meeting a minimum width of $15 \mathrm{~m}$ and for water bodies $\geq 4000 \mathrm{~m}^{2}$ in area.

Hydroflattening corrects for missing information due to absorption of the near-infrared LiDAR signals by water. The hydroflattening process eliminates artifacts in the digital terrain model caused by increased variability in ranges or dropouts in laser returns due to the low reflectivity of water. To address this, larger water bodies were flattened to a consistent water level. However, none of the water bodies present in our imagery (i.e., the areas including and around the transects at each site) were large enough to have been hydroflattened.

\section{Electrical resistance tomography}

We used an Advanced Geosciences Incorporated (Austin, Texas) SuperSting R8 eight-channel portable induced polarization galvanic earth resistivity meter for the ERT measurements. Similar arrays have proven exceptional in identifying and mapping permafrost in the continuous zone of the high Arctic (Hubbard et al., 2013); in discontinuous permafrost in the Yukon, Canada (Lewkowicz et al., 2011); and near Fairbanks (Osterkamp et al., 1980). Permafrost resistivity values have been established for the Fairbanks area in multiple studies. Resistivity values of $800 \Omega \mathrm{m}$ were reported for syngenetic permafrost near Fairbanks at $-5^{\circ} \mathrm{C}$ (Hoekstra and McNeill, 1973). Permafrost resistivity values of $>600 \Omega \mathrm{m}$ were reported as indicative of permafrost at the CRREL Farmers Loop Permafrost Experimental Station (Douglas et al., 2008). Values of $600-10,000 \Omega \mathrm{m}$ were measured at a pingo located $4 \mathrm{~km}$ west of the Permafrost Experimental Station (Yoshikawa et al., 2006). For the purposes of this study, resistivity values of $1000 \Omega \mathrm{m}$ or greater were deemed indicative of permafrost.

Six cables, each with 14 take-out electrodes, were used at 2-m spacings at four of the sites to achieve a maximum penetration depth into the subsurface of approximately $25 \mathrm{~m}$. At the 1975 site, a 3-m spacing was used to provide a maximum penetration depth of approximately $35 \mathrm{~m}$. A dipole-dipole array was used for all measurements because it has been found to best represent spatial aspects of

Table 1. Transect locations in Universal Transverse Locator (UTM), distances, and elevation information.

Site name (fire year)

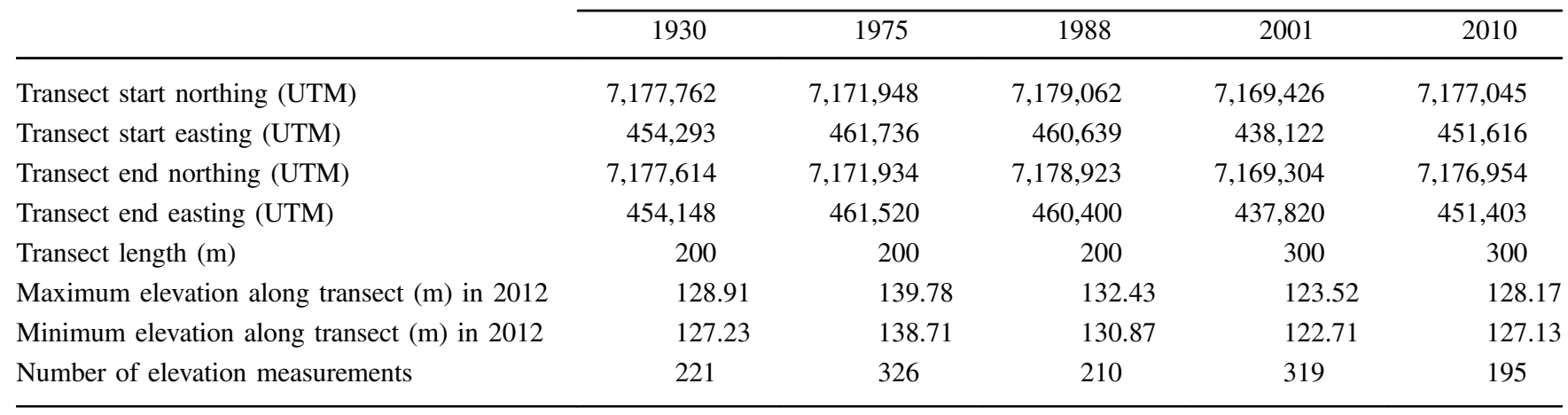


ice-rich terrain and to provide optimal horizontal resolution to detect vertical structures in permafrost terrains (Kneisel, 2006). Contact resistance was measured at each electrode prior to collecting any survey measurements for quality assurance and to check cable connectivity. When contact resistance values were higher than $2000 \Omega \mathrm{m}$, saltwater was added to the electrode installation. Contact resistance was rechecked until adequate resistance was measured. Electrodes were typically $45 \mathrm{~cm}$ long, but electrodes up to $1 \mathrm{~m}$ in length were used in areas with thick moss or vegetation mats. For the 2001 and 2010 sites, there were regions of open water that were too deep (i.e., $>1 \mathrm{~m}$ ) into which we could not install electrodes. To address this, ERT transects were measured along distances at which adequate contact resistance was available. The survey proceeded when the contact resistance was less than $2000 \Omega$ for all electrodes along the 84-electrode line. Table 2 includes information on the location of the electric resistivity transects and the electrode spacing configuration for the ERT transects.

Two-dimensional model interpretation was performed using RES2DINV (Geotomo Software, Penang, Malaysia), which performs smoothing and constrains inversion using finite-difference forward modeling and quasi-Newton techniques (Loke and Barker, 1996; Loke et al., 2003). Using a least-squares inversion, convergence was tested by comparing the change in rms quadratic error between two and five iterations, then three and five iterations, etc., until all five iterations were compared with one another, and the rms error was established. The rms error provides insight into how well mathematically convergence was achieved. When further iterations would not significantly lower the rms values, we accepted those results and provide the rms value for comparison.

\section{RESULTS}

High-resolution satellite imagery, vegetation determinations, airborne LiDAR imagery (except the 1975 site), dGPS surface elevations, seasonal thaw depths, and ERT measurements from all five fire scar locations are provided in Figures 2-6. They represent a chronosequence of areas burned by wildfires in 1930, 1975, 1988, 2001, and 2010. Below, we describe the varying patterns of vegetation, topography, thaw depths, soils, and ERT for each site in the different-aged fire scars. We then compare the permafrost distribution across the sites and evaluate the relationships among biophysical factors.

\section{Biophysical characteristics by site}

At the 1930 fire site (Figure 2), vegetation along the 215-m transect consisted of birch forest ( $23 \%$ of transect), mixed black spruce-birch forest $(11 \%)$, drowned forest with aquatic forbs (10\%), dwarf shrubsphagnum bog (41\%), sedge-sphagnum bog meadow (3\%) along the collapsing margins of the forest, and herbaceous fen (12\%; Table 3 ). The thermokarst features in the collapsing margins of the forest were not identifiable in the LiDAR imagery because the small-surface water bodies absorbed most of the near-infrared LiDAR signals and the data holes they represent were smoothed by hydroflattening. Mean ground-surface elevations of terrain in the mixed black spruce-birch forest $(128.65 \mathrm{~m}$ asl) were approximately $0.6 \mathrm{~m}$ higher than those in the herbaceous fen $(127.60 \mathrm{~m})$, dwarf shrub-sphagnum bog $(128.02 \mathrm{~m})$, or sedge-sphagnum bog meadow $(128.00 \mathrm{~m})$ associated with thermokarst terrain. The birch forest with thermokarst pits had intermediate and highly variable elevations $(128.30 \mathrm{~m})$. Thaw depths indicated that NSP was present in the mixed black spruce-birch forest $($ mean $=53.3 \mathrm{~cm})$ and in the birch forest $(63.3 \mathrm{~cm})$. Seasonal frost was encountered in the dwarf shrub-sphagnum bog $(58.6 \mathrm{~cm})$ and sedgesphagnum bog meadow $(62.4 \mathrm{~cm})$, whereas NSP was absent in the herbaceous fen (unfrozen to $2.5 \mathrm{~m}$ ). Soil cores in the mixed black spruce-birch forest (4-m-deep core at 200-m distance) and in the birch forest (3-m-deep core at $65-\mathrm{m}$ distance) were ice rich and provided additional confirmation of permafrost below these vegetation types. Soils at this site include an upper peat layer (averaging $89 \mathrm{~cm}$ thick) over a mixture of silt loam, sand, and sandy loam, while gravel was encountered at depths of 2.9-3.1 m. The permafrost was dominated by thick-layered, braided ice and pore ice cryostructures. ERT measurements at 2- to 5-m depths across the transect starting at $60 \mathrm{~m}$ show irregular mixed values in the birch forest (7000-20,000 $\Omega \mathrm{m}$ ), low values in the bog $(<500 \Omega \mathrm{m})$, and high values in the mixed black sprucebirch forest (2000-60,000 $\Omega \mathrm{m})$. The ERT profile shows thaw bulbs extending beneath the thin layers of shallow permafrost near the bog margins. The ERT profile suggests that most of the bog is thawed to a depth of at least $22 \mathrm{~m}$. We attribute the slightly elevated ERT values at 117 - to $122-\mathrm{m}$ elevation to unfrozen gravel found at less than a $124-\mathrm{m}$ elevation.

At the 1975 fire site (Figure 3), vegetation along the 342-m transect consisted of mixed black spruce-aspen forest (59\%), black spruce forest (16\%), and low shrub-grass, postburn (25\%). Elevations ranged from $139.7 \mathrm{~m}$ asl in the black spruce forest to $138.8 \mathrm{~m}$ in the low shrub-grass, but distinct collapse-scar features were not evident. No LiDAR imagery was available for this location. Frost

Table 2. Electrical resistivity tomography information for the five fire scar field sites in this study.

\begin{tabular}{|c|c|c|c|c|c|c|c|}
\hline & \multicolumn{7}{|c|}{ Site name (fire year) } \\
\hline & 1930 & 1975 & 1988 & 2001 & 2001 & 2010 & 2010 \\
\hline Geophysical line start (distance in meters along transect) & 54 & -33 & 0 & -26 & 180 & 0 & 130 \\
\hline Geophysical line end (distance in meters along transect) & 219 & 215 & 152 & 140 & 318 & 90 & 200 \\
\hline Electrode spacing (m) & 2 & 3 & 2 & 2 & 2 & 1 & 1 \\
\hline Pixels per unit spacing (horizontal) & 1.01 & 21.89 & 23.91 & 1.01 & 26.33 & 1.01 & 1.01 \\
\hline Root-mean-square error & 5.5 & 12.4 & 13.8 & 2.7 & 10 & 9.5 & 9.9 \\
\hline
\end{tabular}


probe measurements did not conclusively identify permafrost from 0 to $120 \mathrm{~m}$ along the transect. This was confirmed with the three SIPRE cores extracted from this section. However, frost probing and SIPRE cores from 120 to $350 \mathrm{~m}$ did provide information to support the presence of permafrost along that section of the transect. Some of the silt layers were extremely resistant to the frost probe, but SIPRE cores nearby contained unfrozen material. In the mixed forest, near-surface soils were typically thin layers of silt loam

a)

b)
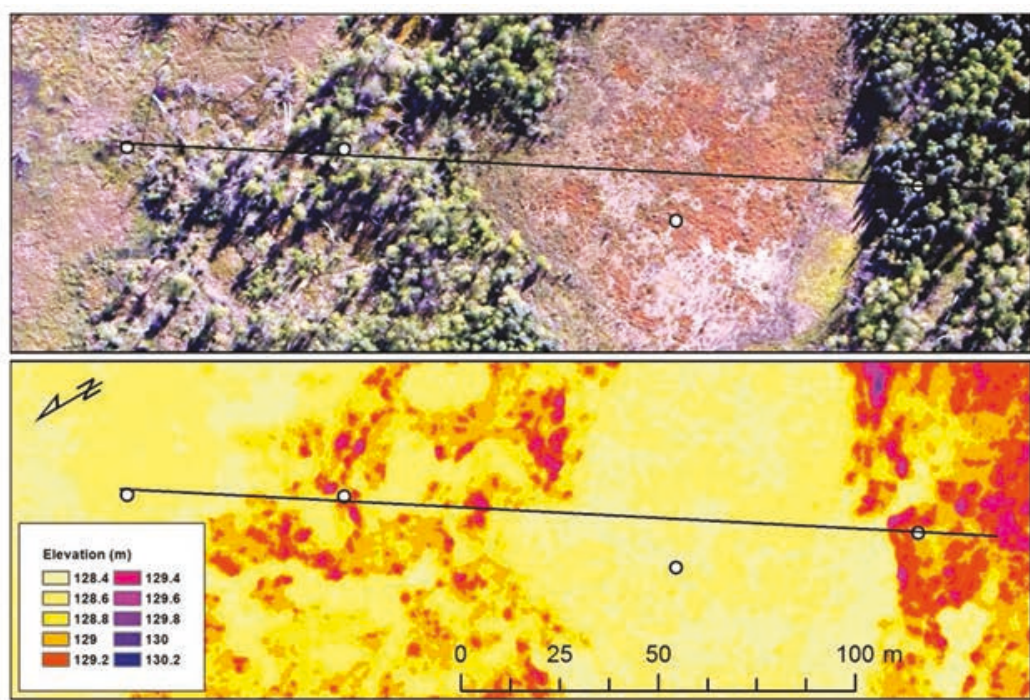

c)

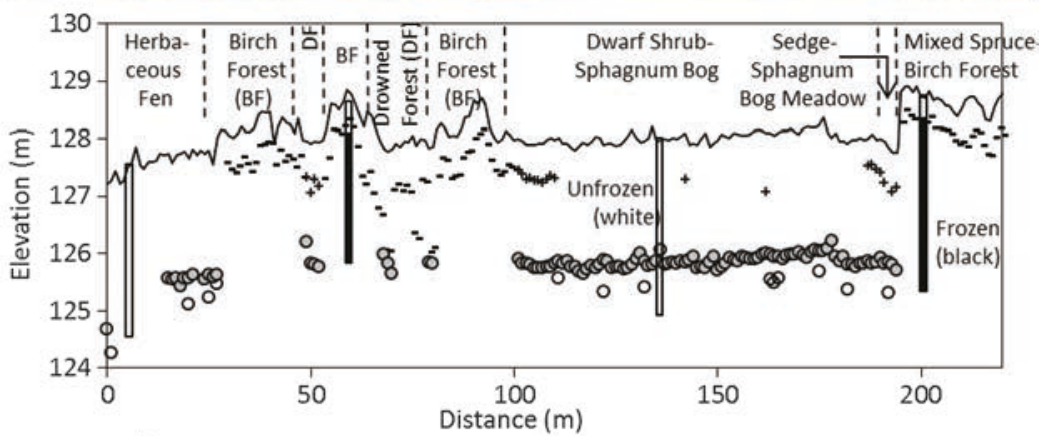

d)

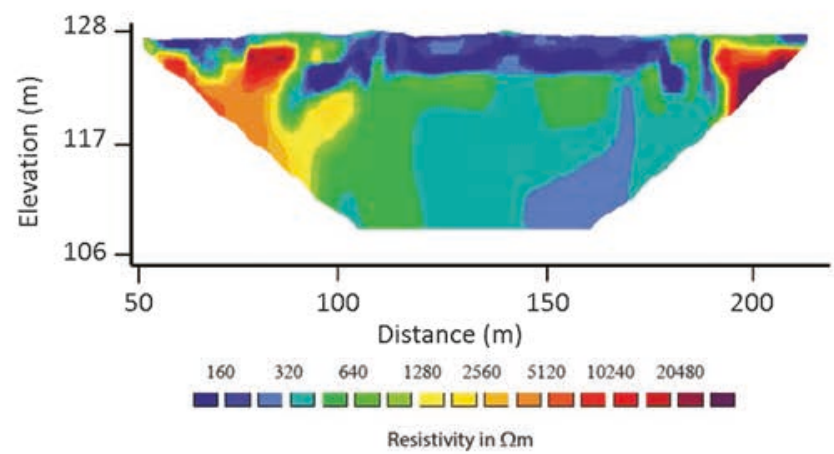

Figure 2. (a) An aerial image of the 1930 fire scar. (b) Airborne LiDAR imagery, shaded by elevation, for the same region presented in the upper panel. The bold line indicates the location and length of the transect at the site, whereas circles denote locations where SIPRE cores were collected. (c) A detailed cross section of the vegetation, ground elevation, SIPRE core depths, seasonal thaw depths, and elevations of unfrozen material across the transect. Black line, ground surface; dashes, thaw-depth elevation in 2012; crosses, seasonal frost elevation in 2012; open circles, unfrozen elevation in 2012; and gray circles, unfrozen elevation in 2014. (d) ERT survey results across the transect. underlain by sandy loam and sands, with gravels occurring within soil cores taken 3 and $40 \mathrm{~m}$ along the transect. In the swale at $190 \mathrm{~m}$ along the transect, permafrost was found at a depth of $140 \mathrm{~cm}$. In the black spruce forest at $240 \mathrm{~m}$, permafrost was found at a depth of $128 \mathrm{~cm}$. The ERT values were generally less than $600 \Omega \mathrm{m}$, suggesting an absence of permafrost at most of the site. However, some thin horizontal features with ERT values greater than $1000 \Omega \mathrm{m}$ were likely indicative of small lenticular bodies of permafrost. They all were more than $3 \mathrm{~m}$ below the ground surface, so our frost probe and soil coring would not have encountered them. Because our coring and thaw probe measurements could not reach these depths, we cannot definitively say whether or not there was permafrost at these locations. However, based on the strong relationship between ERT values >600 $\Omega \mathrm{m}$ and permafrost at our sites and in numerous other studies in similar terrains, we believe that these locations do have small lenses of permafrost at these depths. The permafrost is present under a near-surface talik, and it is unclear whether this permafrost has been thawing down to its present vertical elevation or whether permafrost has been aggrading upward at these sites.

At the 1988 fire site (Figure 4), which also was burned previously around 1950, vegetation along the 215-m transect consisted of birch forest $(56 \%)$, grass meadow (12\%), and sedge-sphagnum bog $(31 \%)$. Mean surface elevations in the birch forests $(131.99 \mathrm{~m}$ asl) were approximately $0.7 \mathrm{~m}$ higher than those in the bog $(131.28 \mathrm{~m})$, whereas mean elevations in the grass meadow associated with newly developing permafrost within a collapse-scar bog had intermediate elevations (131.49 m). Mean thaw depths in late August 2012 in the birch forest $(58.3 \mathrm{~cm})$ and grass meadow $(56.3 \mathrm{~cm})$ were relatively shallow and thus indicative of the presence of permafrost, whereas the sedge-sphagnum bog had slightly deeper thaw depths $(66.4 \mathrm{~cm})$. Soils at this site had a very thick peat layer (averaging $176 \mathrm{~cm}$ ) on top of a mixture of silt loam and layered sand-silt. Cryostructures in the permafrost soil consisted of organic-matrix ice, lenticular ice, and ataxitic ice. A soil core in the grass meadow (at $60 \mathrm{~m}$ ) was frozen from 51 to $240 \mathrm{~cm}$, and it was unfrozen from 240 to $350 \mathrm{~cm}$, indicating that a new thin layer of permafrost has been aggrading. Gravel was found at $340 \mathrm{~cm}$. The edges and center of the bog yielded the deepest frost probe and lowest ERT values along the transect. In the bog center (65-71 m), permafrost was not encountered by frost probing in the upper $2.5 \mathrm{~m}$. The low ERT values in the center of the bog suggest it is thawed to at least $8 \mathrm{~m}$ in depth. Contact resistance could not 
be established beyond $152 \mathrm{~m}$ because another bog (from 152 to $190 \mathrm{~m}$ ) had standing water. Some surface-water features are visible in the aerial image, but, as with the 1930 site, they are smoothed by the LiDAR hydroflattening.

At the 2001 fire site (Figure 5), vegetation along the 320-m transect consisted of low shrub-grass, postburn (54\%), sedge-sphagnum bog meadow (36\%), and drowned forest, postburn (10\%; Table 3). Mean surface elevations of the low shrub-grass, postburn $(123.11 \mathrm{~m})$ were only slightly higher than those in the sedge-sphagnum bog meadow $(122.95 \mathrm{~m})$ and drowned forest, postburn $(122.80 \mathrm{~m})$. The LiDAR imagery from this site exhibits the small (i.e., $<1 \mathrm{~m}$ ) changes in ground surface elevation associated with the changing land surface characteristics from elevated forests to lower elevation bog features. Mean thaw depths in late August 2012 in the low shrub-grass, postburn $(117.7 \mathrm{~cm})$ and drowned forest, postburn $(114.0 \mathrm{~cm})$ were similar, and they were slightly deeper in the sedge-sphagnum bog meadow $(139.7 \mathrm{~cm})$, but at many locations, permafrost was not encountered. Upper mineral soils in the forested sections are fine textured silt loams to depths of approximately $2 \mathrm{~m}$, underlain by sands and gravels with permafrost consisting of layered, braided, and pore ice features. The mean organic layer thickness in the burned forest was $14 \mathrm{~cm}$. At this site, there is also an evident correlation between the frost probe depths and the morphology of the subsurface permafrost. For example, from 0 to $30 \mathrm{~m}$, the frost probe depths go from $>1 \mathrm{~m}$ to approximately $50 \mathrm{~cm}$ at the edge of the small bog located from 25 to $55 \mathrm{~m}$ along the transect. Frost probe depths increase for the $5 \mathrm{~m}$ on either side of the bog. A collapse-scar bog from 100 to $180 \mathrm{~m}$ along the transect had an area of standing water from 140 to $180 \mathrm{~m}$ into which low contact resistance values could not be established. The ERT cross sections from the two sets of measurements at this site show the large difference in $\Omega \mathrm{m}$ values between frozen and thawed material. The low-ERT values in the center of the small bog (at approximately $45 \mathrm{~m}$ ) indicate it is unfrozen to a ground elevation of $100 \mathrm{~m}$. Along the margins of the small bog, there appears to be lateral thawing underneath the upper permafrost. The low ERT values in the large bog (from 100 to $140 \mathrm{~m}$ ) suggest it is unfrozen to the maximum depths of the ERT measurements. From 180 to $240 \mathrm{~m}$, the frost probe depths correspond well with the permafrost surface inferred by ERT. From 238 to $270 \mathrm{~m}$, the frost probe depths are close to the maximum we could measure $(2.7 \mathrm{~m})$, and a thin horizontal layer with resistivity values between approximately 700 and $1000 \Omega \mathrm{m}$ in this area indicates that there is a thin (i.e., a few meters thick) lens of permafrost. This region is characterized by a small bog feature. The unfrozen zone underlying this bog appears to extend to the area beneath the burned black spruce forest from approximately 270 to $300 \mathrm{~m}$, but the permafrost beneath the burned black spruce on the other side of the bog remained intact at depth. From 270 to $318 \mathrm{~m}$, the frost probe and ERT values again correspond well with one another, indi- cating that both methods accurately identified the top of the permafrost table.

At the 2010 burn site (Figure 6), vegetation along the 200-m transect consisted of forb meadow, postburn (42\%), sedge-sphagnum bog meadow (45\%), low shrub-tussock, postburn (9\%), and drowned forest, postburn (3\%). Mean surface elevations in the forb meadow, postburn $(127.55 \mathrm{~m})$ and low shrub-tussock, postburn $(127.50 \mathrm{~m})$ were only approximately $0.3 \mathrm{~m}$ higher than the sedge-sphagnum bog meadow (127.25 m). Mean thaw depths were much higher in the drowned forest, postburn $(169.7 \mathrm{~cm})$ and forb meadow, postburn $(115.9 \mathrm{~cm})$ compared with the low shrub-tussock, postburn $(83.3 \mathrm{~cm})$. Permafrost soils typically had a thin organic layer over silt loam, with fluvial sand and gravel found at 2.73-m depth. Permafrost includes layered, braided, and pore ice features. The ERT measurements were separated into two sections because the middle of the transect had standing water and floating mat vegetation, for which low-contact resistances could not be established. Low-ERT values $(<500 \Omega \mathrm{m})$ from 22 to $45 \mathrm{~m}$ indicate permafrost is absent in the small bog feature. It is possible that the permafrost table is present approximately $6 \mathrm{~m}$ below the ground surface, as indicated by the elevated resistivity values at that depth,

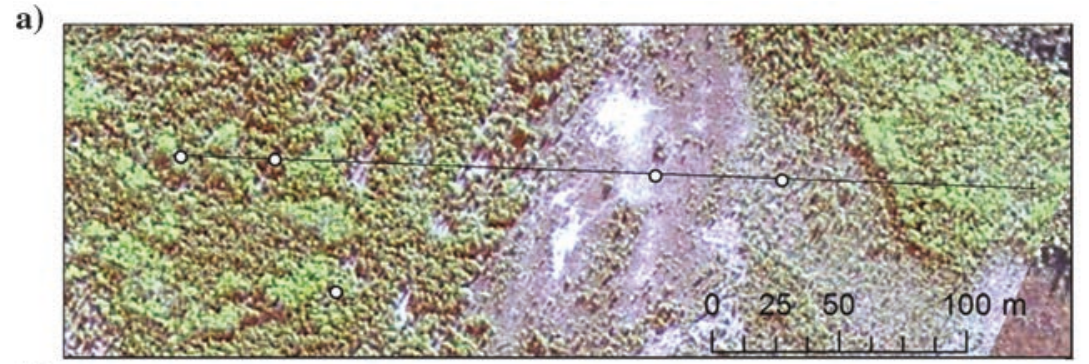

b)

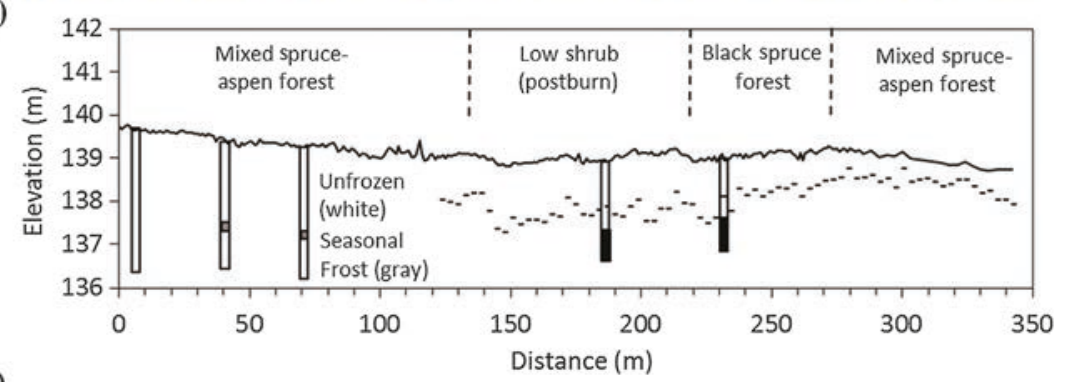

c)

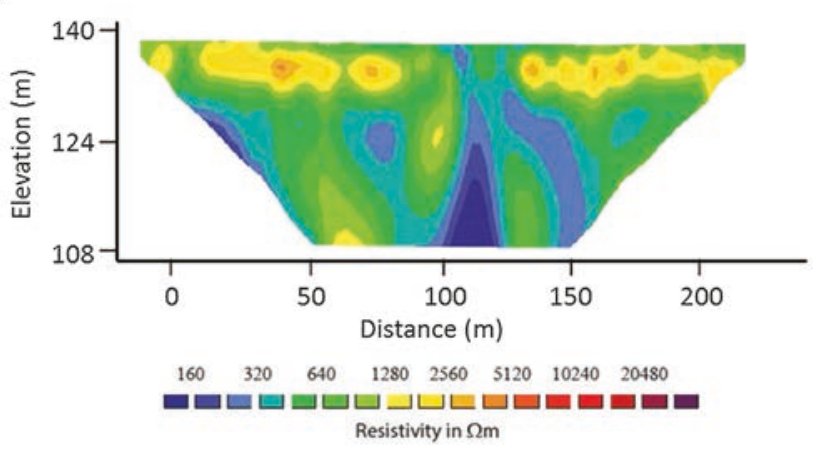

Figure 3. (a) An aerial image of the 1975 fire scar. The bold line indicates the location and length of the transect at the site, whereas circles denote locations where SIPRE cores were collected. (b) A detailed cross section of the vegetation, ground elevation, SIPRE core depths, seasonal thaw depths, and elevations of unfrozen material across the transect. Black line, ground surface and dashes, thaw-depth elevation in 2012. (c) ERT survey results across the transect. 
but this depth is greater than our frost probe or SIPRE coring could reach, so it cannot be verified. From approximately 50 to $90 \mathrm{~m}$, the ERT and frost probe measurements indicated a slowly increasing depth to the top of the permafrost below the sloping ground surface. This section of the transect is a gradually downward dipping mound with somewhat consistent seasonal thaw depths. Due to the different vertical scales in Figure 6c and 6d, this section of the transect appears flat-lying in the ERT cross section. The collapse-scar bog from 90 to $145 \mathrm{~m}$ had low-ERT values (approximately $300 \Omega \mathrm{m}$ ). A small feature exhibiting elevated ERT measurements, indicative of the presence of a permafrost table, is present from 140 to $155 \mathrm{~m}$ but is slightly deeper than the 2.5 -m-long probe could extend. The permafrost table, as indicated by ERT and frost probe measurements, slowly gained elevation with distance away from the bog (i.e., from 155 to $200 \mathrm{~m}$ ). The collapse-scar features and forested regions at this site are readily visible in the LiDAR imagery.

\section{a)}

b)
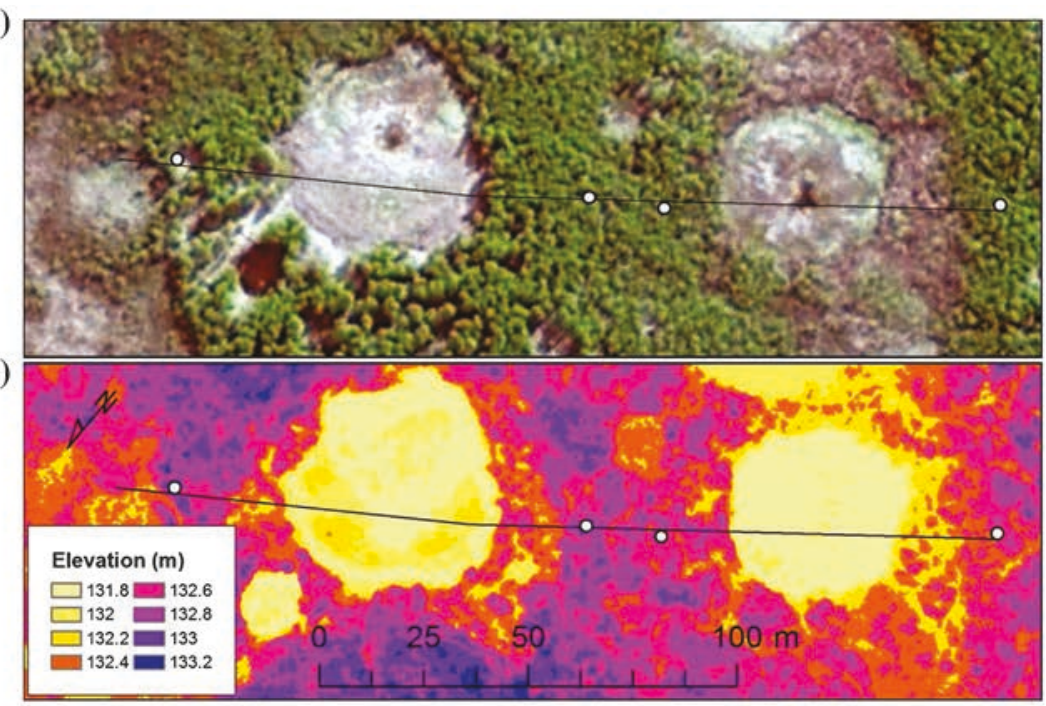

c)

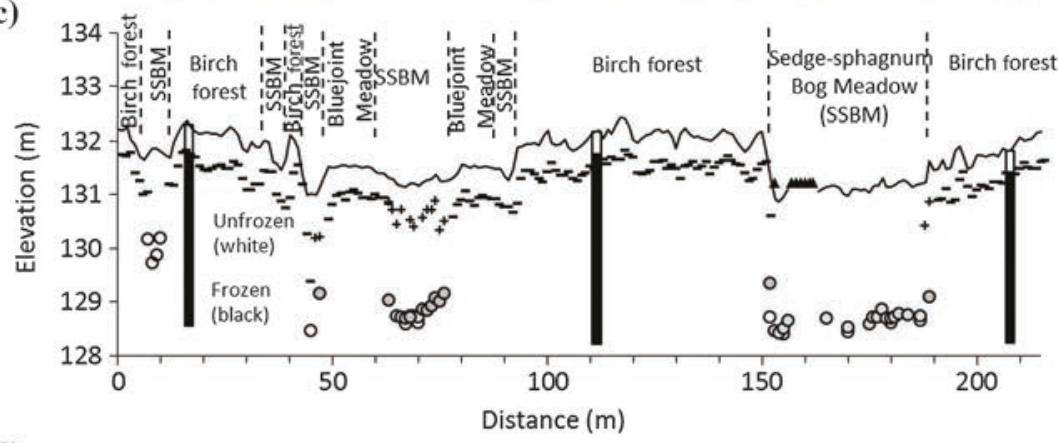

d)

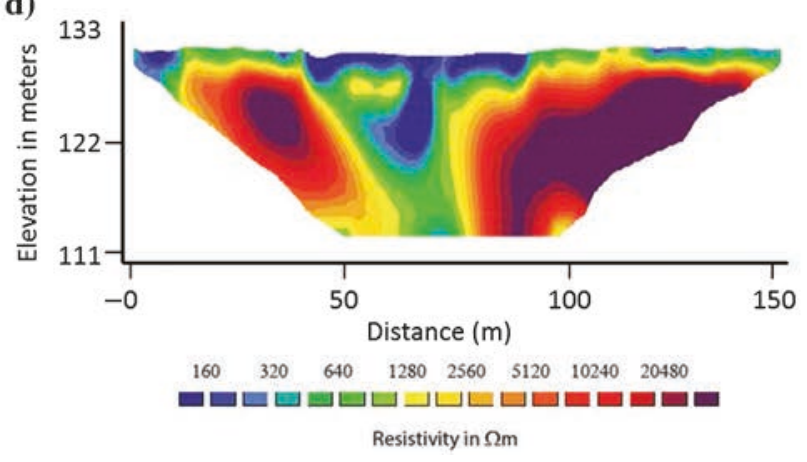

Figure 4. (a) An aerial image of the 1988 fire scar. (b) Airborne LiDAR imagery, shaded by elevation, for the same region presented in (a). The bold line indicates the location and length of the transect at the site, whereas circles denote locations where SIPRE cores were collected. (c) A detailed cross section of the vegetation, ground elevation, SIPRE core depths, seasonal thaw depths, and elevations of unfrozen material across the transect. Black line, ground surface; black triangle, water surface; dashes, thaw-depth elevation in 2012; crosses, seasonal frost elevation in 2012; open circles, unfrozen elevation in 2012; and gray circles, unfrozen elevation in 2013. (d) ERT survey results across the transect.

\section{Permafrost distribution}

Our field sites were selected based on their ability to represent a chronosequence of time since the fires. The burn severity for the 1930 and 1975 fires is unclear at our field locations. As such, we are not able to make inferences on how or at what rate the permafrost responds to fire or to postfire vegetation succession. Because there is some spatial heterogeneity in the soil composition and physical location of each site, it is impossible to compare elevation measurements or depths with permafrost across the five sites. However, at each site, the soils and elevation gradients are homogeneous enough that biophysical measurements from a given site can be compared. The first analysis of biophysical characteristics we performed was the presence (or absence) of permafrost at a variety of depths at each site. Permafrost abundance at the 1.5-m depth determined from frost probing ranged from $40 \%$ to $74 \%$ across the 1930 , 1988, 2001, and 2010 fire scar sites (Figure 7). Determination of permafrost extent at the 1975 burn site was problematic because of inconsistencies in probing the sandy soils; generally, the soils appeared to be free of NSP, but probing was unreliable, and the site was excluded from the analyses. The permafrost extents were similar at a 2.5-m depth, except at 2001, where NSP increased to $66 \%$, indicating that a thin closed talik had developed between the active layer and permafrost along a portion of the transect due to fire and thermokarst.

ERT measurements indicate that permafrost degradation is occurring by vertical thawing from the surface and lateral thawing at the margins of deeper thermokarst features. Thaw probing and ERT measurements indicate vertical thawing, and shallow thermokarst pits were present at the 1930 fire site (60-80-m distance), the 2001 fire site (0-80 and 235-270-m distances), and the 2010 fire site (20-40 and 150-180-m distances). Shallow closed taliks (depressions in the permafrost table with thawed material below the active layer) from vertical thawing down to an approximately 2 -m depth were evident at the 2001 and 2010 fire sites. Some of these may be open taliks (they completely penetrate the permafrost), but we cannot definitively characterize them without deeper ERT measurements. 
Lateral degradation from subsurface thawing often created thawed "niches" at depths from 2 to $10 \mathrm{~m}$, and frozen "shelves" of NSP, where subsurface lateral thawing was more rapid than surface thawing. At the 1930 fire site, a thawed niche was evident at approximately $90 \mathrm{~m}$ (approximately 5-m maximum width) and approximately 200-m (approximately 3-m) distances, based on ERT contours within the 600 - to $1000-\Omega \mathrm{m}$ range. At the 2001 fire site, a thawed niche was evident at an approximately 25-m distance (approximately $6 \mathrm{~m}$ ), approximately $50-\mathrm{m}$ distance (approximately $2 \mathrm{~m}$ ), approximately 245-m distance (approximately $5 \mathrm{~m}$ ), and approximately 300-m distance (approximately $9 \mathrm{~m}$ ). At the 2010 fire site, a broadly curving niche was evident at approximately 45-m distance (approximately $3 \mathrm{~m}$ ).

A comparison between permafrost distribution measured by ERT and thaw probing found relatively high agreement among the methods (Figure 8). For locations determined to be frozen at the $2.5-\mathrm{m}$ depth by probing, ERT indicated that permafrost was present at $3 \mathrm{~m}$ for $81.7 \%$ of 487 observations. For locations determined to be unfrozen at the 2.5-m depth by probing, ERT indicated that permafrost was present at $81.3 \%$ of 246 observations.

\section{Permafrost relationships with biophysi- cal factors}

Strong associations were found between surface vegetation, topography, thaw depths, and permafrost extent. Across all transects (excluding the 1970 fire site), mean relative heights (based on the mean elevation of bogs, which were the lowest elevation terrain at each transect) were consistently higher in forest types $(0.58-0.65 \mathrm{~m})$ compared with bogs and fens $(-0.40-0.02 \mathrm{~m})$, whereas postburn shrub and meadow ecotypes had intermediate heights $(0.07-0.30 \mathrm{~m})$. Drowned forests from thermokarst had some of the lowest relative heights $(-0.07-0.20 \mathrm{~m})$. Mean thaw depths were shallowest in the forest types $(53.3-59.8 \mathrm{~cm})$ and deepest in the postburn types $(83.3-126.8 \mathrm{~cm})$. NSP was generally absent in the bogs, but where it was present along thawing margins, the morphology of the margins was highly variable.

Permafrost extent at the 2.5-m depth was nearly $100 \%$ in the forest type and early successional ecotypes after fire (postburn), highly variable in drowned forests $(25 \%-76 \%)$, and sporadic in fens and bogs (0\%-16\%), where NSP mostly occurred along thawing margins (Figure 9). The permafrost presence was moderately related $\left(r^{2}=0.52\right)$ to relative elevations when elevations from each site were compared with measurements from that site and then pooled across all sites (Figure 10), with permafrost nearly always present (93\%-100\% of observations) when relative heights of the surface were $>5 \mathrm{~cm}$ and mostly absent $(0 \%-25 \%)$ when heights were $<5 \mathrm{~cm}$. The main exceptions from the trend were for the drowned forest type, where

a)

b) the transect.
NSP frequently occurred $(25 \%-75 \%)$ even when heights were $<5 \mathrm{~cm}$.

\section{DISCUSSION}

\section{Permafrost distribution and electrical resistivity tomography}

Thaw probing and ERT surveys found permafrost to be sporadic to discontinuous along the transects due to permafrost degradation.
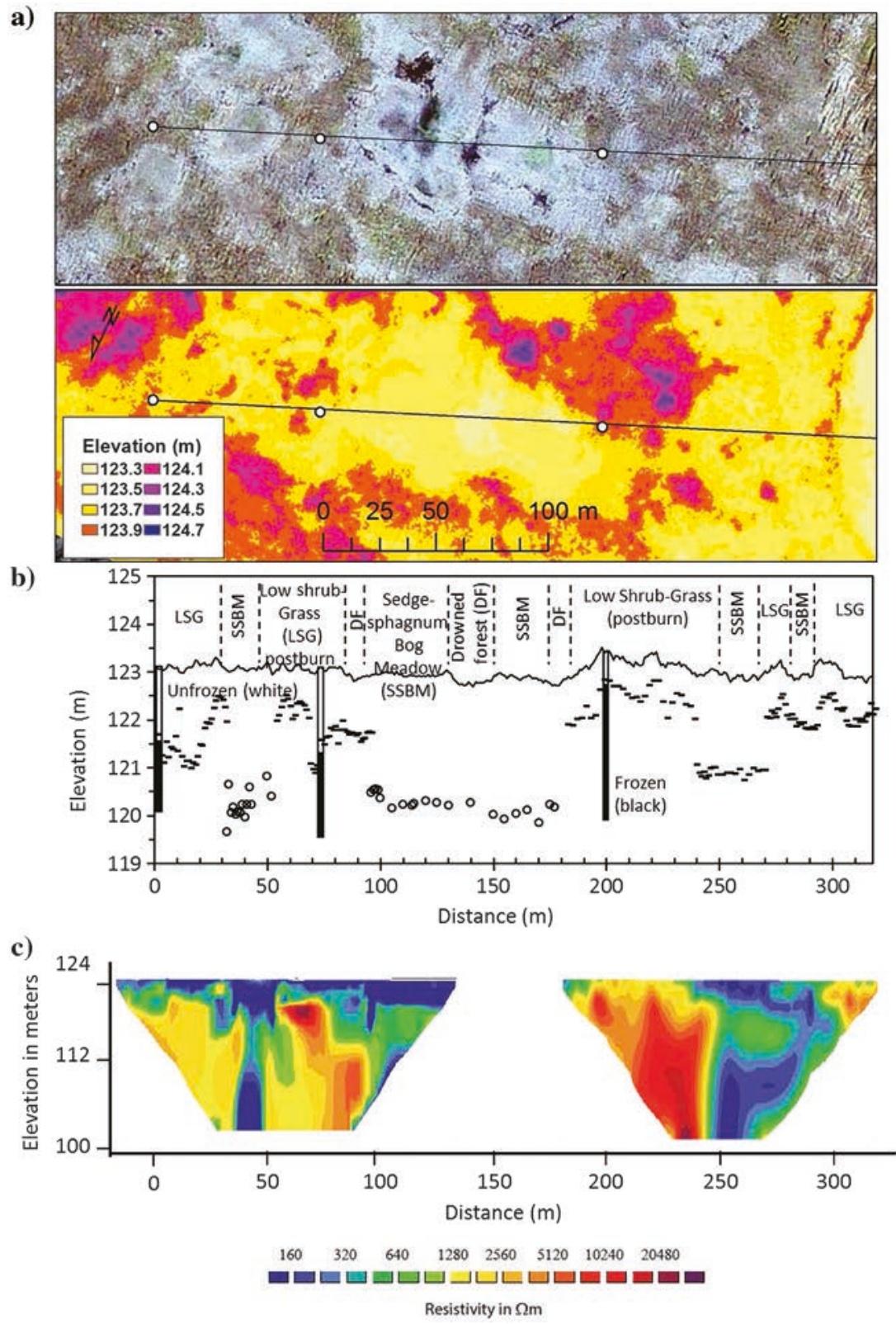

Figure 5. (a) An aerial image of the 2001 fire scar. (b) Airborne LiDAR imagery, shaded by elevation, for the same region presented in the upper panel. The bold line indicates the location and length of the transect at the site, whereas circles denote locations where SIPRE cores were collected. (c) A detailed cross section of the vegetation, ground elevation, SIPRE core depths, seasonal thaw depths, and elevations of unfrozen material across the transect. Black line, ground surface; dashes, thaw-depth elevation in 2012; and open circles, unfrozen elevation in 2012. (d) ERT survey results across 
The mean $(59 \%)$ and range $(42 \%-75 \%)$ of permafrost lateral extent (frequency of occurrence) at the 2.5-m depth along our transects based on thaw probing were similar to the permafrost extent of $53 \%$ previously estimated for a small area near the 1930 fire site (Jorgenson et al., 2001) and 48\% for the broader Tanana Flats (Osterkamp et al., 2000) based on photo interpretation. The ERT surveys, however, also provide information on the distribution of deeper permafrost and the morphology of the thawing boundary along the transition zones.

a)

b)

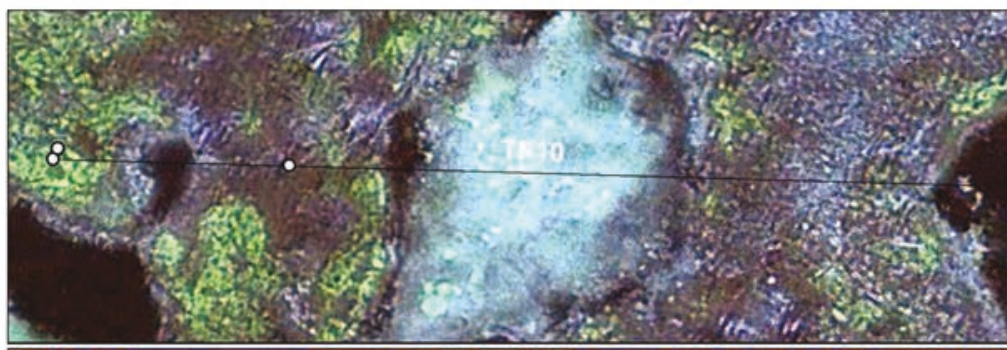

c)
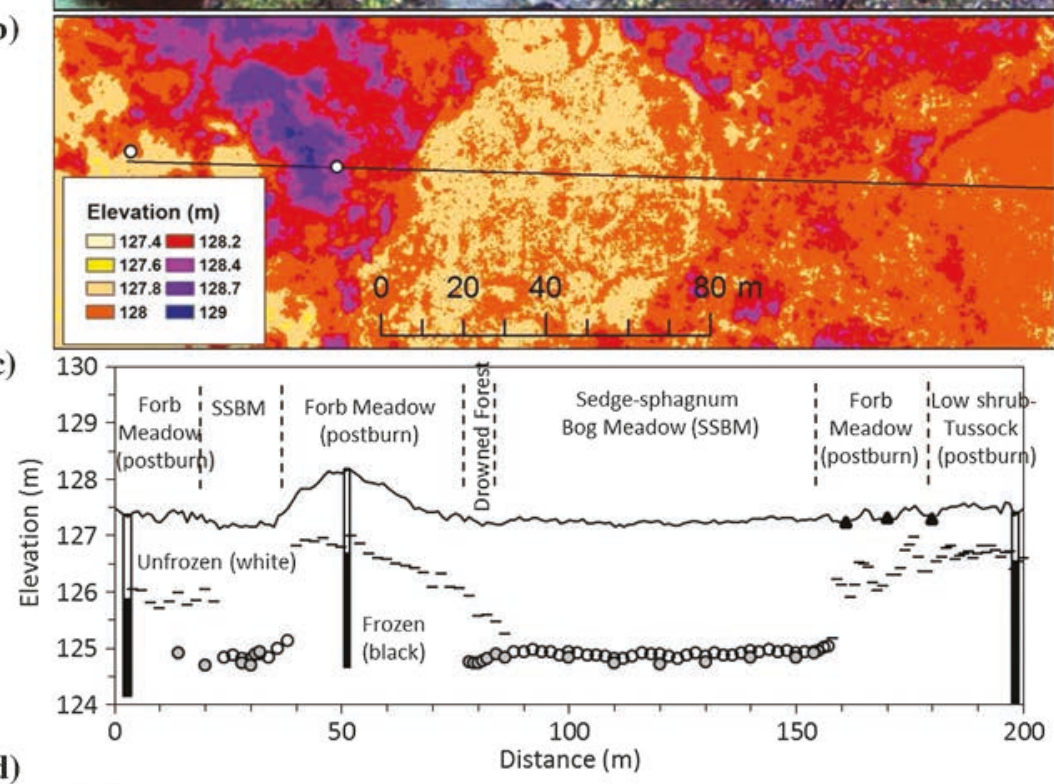

d)

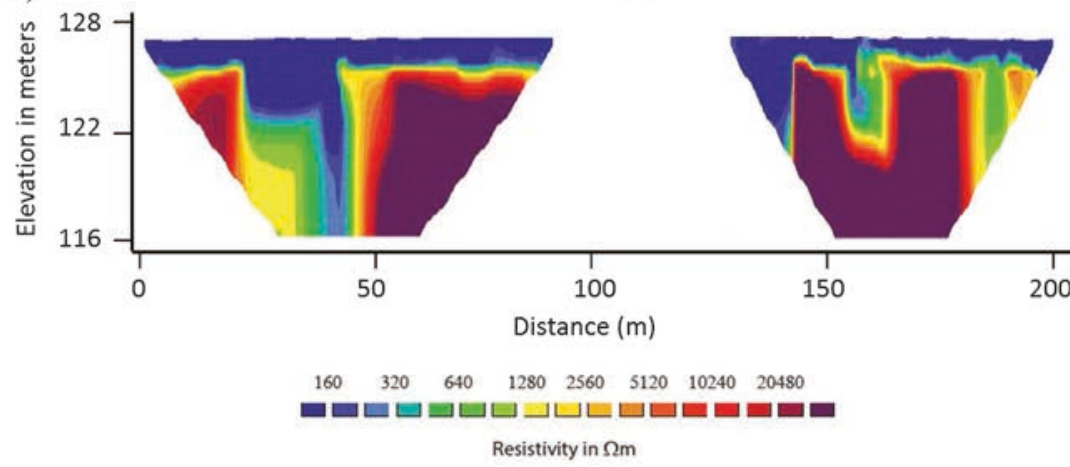

Figure 6. (a) An aerial image of the 2010 fire scar. (b) Airborne LiDAR imagery, shaded by elevation, for the same region presented in the upper panel. The bold line indicates the location and length of the transect at the site, whereas circles denote locations where SIPRE cores were collected. (c) A detailed cross section of the vegetation, ground elevation, SIPRE core depths, seasonal thaw depths, and elevations of unfrozen material across the transect. Black line, ground surface; black triangle, water surface; dashes, thaw-depth elevation in 2012; open circles, unfrozen elevation in 2012; and gray circles, unfrozen elevation in 2013. (d) ERT survey results across the transect.
As shown in this and other studies, ERT surveys provide a robust the surface $2.5 \mathrm{~m}$, for which the thaw probe could reach (Figure 8). This is similar to coupled measurement campaigns reported for continuous permafrost in the high Arctic (Hubbard et al., 2013) and discontinuous permafrost in the Yukon of Canada (Lewkowicz et al., 2011).

The ERT measurements show a complex distribution of subsurface permafrost resulting from vertical surface and lateral thawing along the margins of thermokarst bogs and fens. Although previous studies of thermokarst in peatlands have documented the presence of a thin permafrost shelf and underlying thermal niche along degrading margins (Jorgenson et al., 2012; O'Donnell et al., 2012), our new ERT data provide much broader and more definitive evidence of this lateral degradation in the subsurface. Information on the geomorphology of these thawed-frozen transitions could be used to support thermal and hydrologic modeling efforts to project the response of permafrost and subsurface groundwater flows to a warming climate. Some of these degradation features will lead to formation of taliks, which could then provide a positive feedback to further permafrost thaw, when warm surface or shallow subsurface waters interact with the remaining permafrost.

With projected climate warming in Alaska, the heterogeneous subsurface matrix of discontinuous permafrost likely will respond in unpredictable ways. The subsurface zones where permafrost thaw are most likely to cause topographic and hydrogeologic changes are the transitional margins between frozen and thawed ground. A current limitation in the application of the ERT technique is it is time consuming and requires ground-level measurements. A promising extension of ERT measurement capabilities would be a greater application of airborne platforms, such as AEM (Minsley et al., 2012). When combined with ground-based ERT and thaw probe measurements, the AEM technique could allow for the extrapolation of AEM results across a broader spatial scale.

\section{Terrain-permafrost relationships}

Although we found that vegetation and topography are effective at distinguishing permafrost presence/absence, only ERT is able to definitively map subsurface permafrost distribution. At sites with thawed zones surrounded by permafrost, there were strong relationships between permafrost morphology inferred by ERT and the landscape features evident on satellite 
imagery and determined by thaw probing. The bog and forest features that characterize the Tanana Flats Lowlands are easy to identify in aerial and LiDAR imagery. At our study sites, the bogs occurred in topographic lows surrounded by forests that occurred at higher elevations. Overall, our transects crossed seven bog features that were greater than $10 \mathrm{~m}$ across. The distribution of permafrost in collapse-scar bogs was variable, however, and it was related to depth and bog age. In one bog at the 1988 site (Figure 4), there was a small patch of grass meadow (49-63 $\mathrm{m}$ distance), which was underlain by newly aggrading permafrost. One of the three bog features at the 2001 fire scar (Figure 5) was found to be underlain by permafrost (from 238 to $270 \mathrm{~m}$ ), although we suspect the thaw probing that indicated permafrost at depth was not reliable because a single probe in 2014 did not find permafrost. In young sedge-sphagnum bog meadows that form soon after surface thawing, permafrost determinations were inconsistent between probing (16\%) and ERT (41\%), probably due to the problems with probing and reliability of ERT at shallow depths. In contrast, older dwarf shrub-sphagnum bogs had similarly low permafrost occurrence for probing (3\%) and ERT $(9 \%)$. We attribute the difference to the time lag for deeper permafrost to thaw under younger bogs.

Vegetation is a strong indicator of permafrost distribution when shallow permafrost is present. The vegetation and soil composition at a given site play major roles in controlling the thermal regime. Fire, especially high-severity fires, can remove this insulating surface organic layer and lead to the rapid degradation of permafrost (Brown et al., 2015). Although our fire chronosequence was selected to represent a variety of time lapses since fire, we do not have information on the severity of the 1930 or 1975 fires. As such, we do not compare the soil or vegetation characteristics at one site with another.

In our study, we found permafrost nearly always present under lowland forests and nearly always absent in herbaceous fens and old sphagnum bogs. Similarly, Jorgenson et al. (1999) found permafrost occurred frequently $(>83 \%)$ in lowland needle-leaf, mixed, and broad-leaf forests, but it was always absent in lowland bogs and meadows $(0 \%)$. These vegetation indicators appear highly reliable for ice-rich lowland forests, where thermokarst lowers the ground surface, increases water saturation, and causes dramatic changes in vegetation type. Vegetation spectral indices and land cover mapping derived from Landsat or SPOT imagery were the primary drivers for mapping permafrost distribution in the Yukon Flats (Pastick et al., 2014) and the Trans-Alaska Pipeline System corridor in central Alaska (Panda et al., 2012).

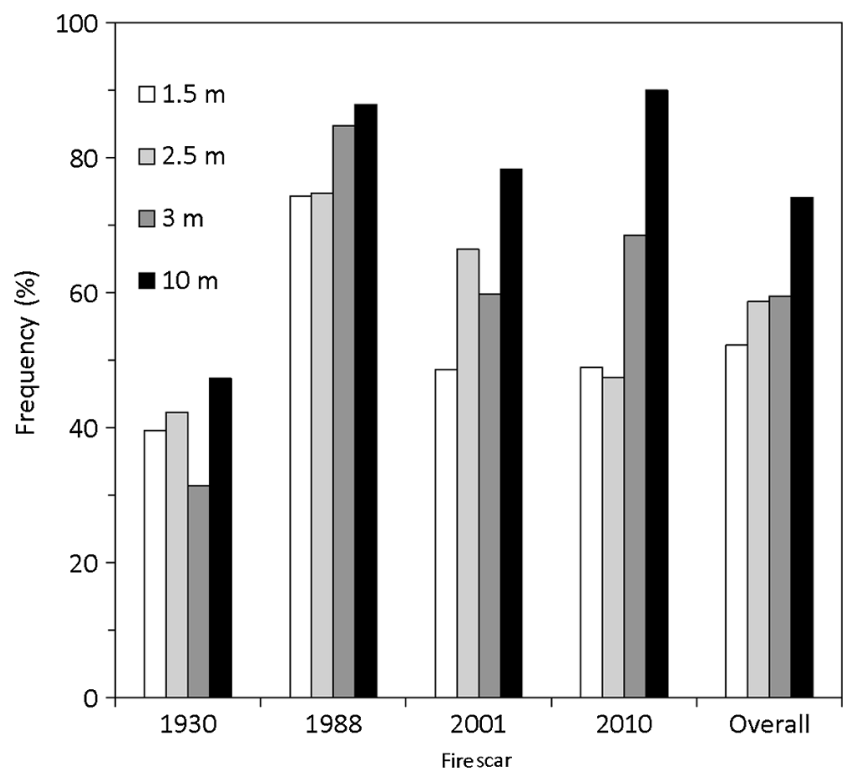

Figure 7. A histogram of permafrost frequency (in percent) for five depths at each fire scar. Frost probe measurements are used for the $1.5-\mathrm{m}$ population, whereas ERT measurements (i.e., values $>600 \Omega \mathrm{m})$ are used for the $2.5-, 3-$, and $10-\mathrm{m}$ populations.

Table 3. Abundance (\% of transect) of ecotypes at the study sites on the Tanana Flats.

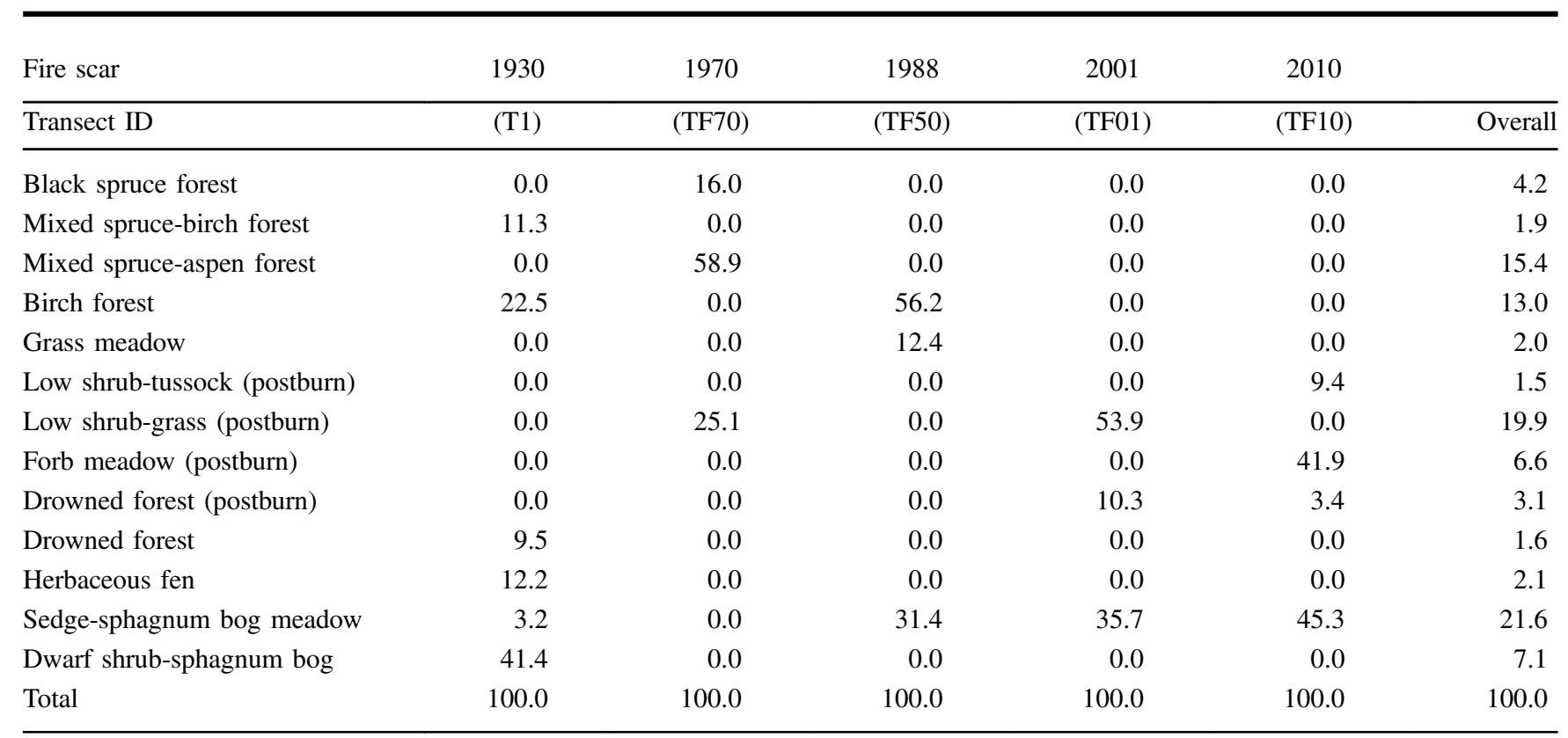


LiDAR and synthetic aperture radar (SAR), particularly repeat imagery analysis, have provided valuable information on how and where permafrost landscapes respond to climate warming and disturbance (Aberman et al., 2009; Marsh et al., 2009; Stevens and Wolfe, 2012; Hubbard et al., 2013; Jones et al., 2013). SAR has proved valuable in quantifying ground subsidence in the high Arctic (Liu et al., 2012) and likely has utility in measuring patterns and rates of landscape change in the discontinuous permafrost zone.

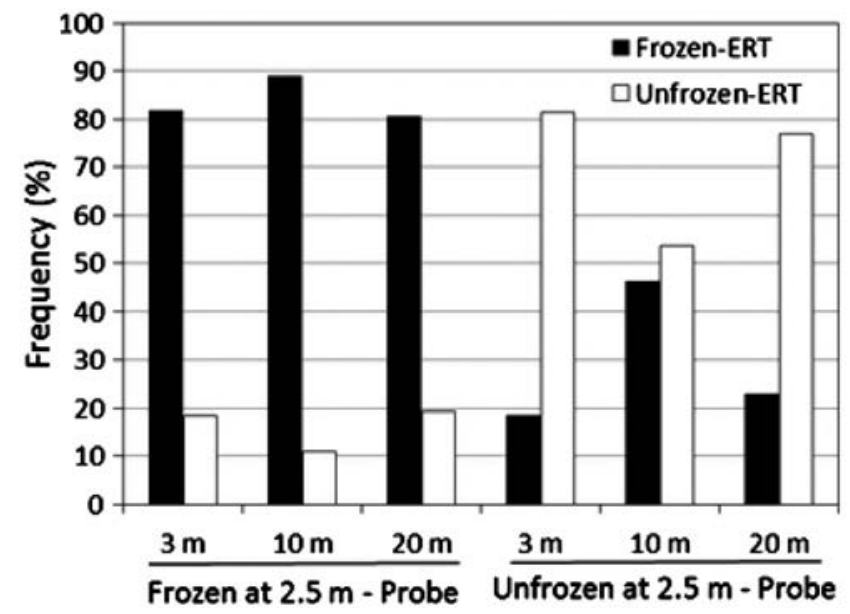

Figure 8. Correlation between permafrost status determined by thaw probing and by ERT across the 1930, 1988, 2001, and 2010 fire scar transects. The frequencies are grouped for locations where soil was frozen or unfrozen at $2.5 \mathrm{~m}$ by probing, with frequencies of frozen and unfrozen ground at 3-, 10-, and 20-m depths as determined by ERT (unfrozen when $\Omega \mathrm{m}<600$ and frozen when $\Omega \mathrm{m}>600$ ).

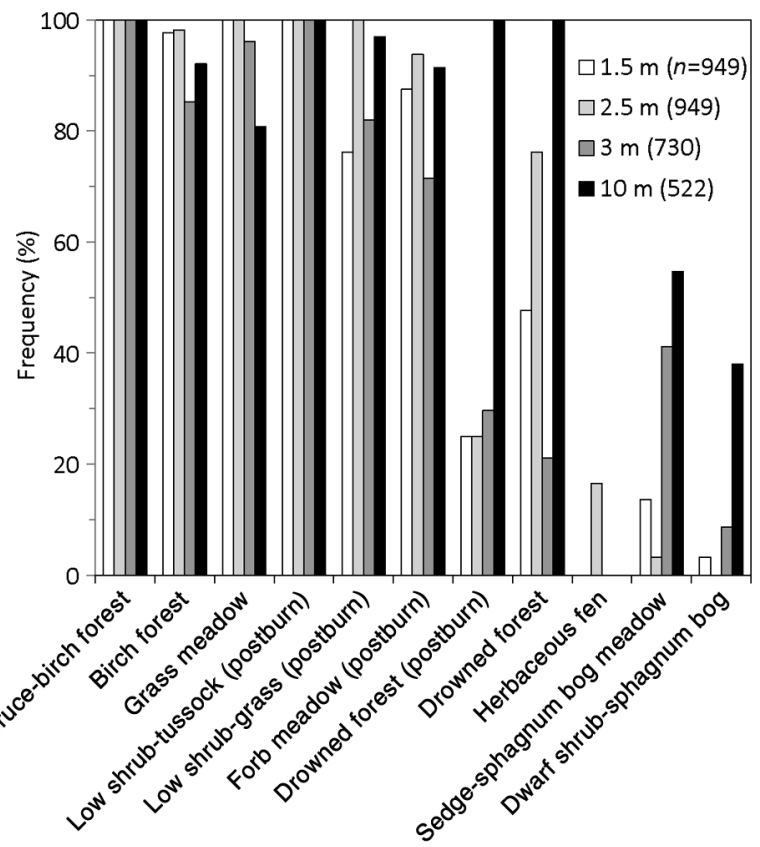

Figure 9. A histogram of the percent frequency of permafrost, by depth, across the 11 ecotypes present at the fire scars.
There is great promise in applying repeat LiDAR to estimating the areal extent of thermokarst development and surface subsidence when permafrost thaws. Being able to map rates of ground surface subsidence along wetland features such as bogs, fens, ephemeral and emerging streams, and lake margins would greatly add to our ability to predict how and where surface and shallow subsurface hydrology will respond to climate warming or disturbance. However, an important limiting factor is the collapse of the surface below the water level and the poor ability of LiDAR to quantify ground/ sediment surface elevations under water. Furthermore, the accurate identification of the water surface in images collected over time is problematic. The LiDAR used in this study was corrected ("hydroflattened") for streams meeting a minimum width of $15 \mathrm{~m}$ and for water bodies $\geq 4000 \mathrm{~m}^{2}$ in area. The hydroflattening process eliminates artifacts in the digital terrain model caused by increased variability in ranges or dropouts in laser returns due to the low reflectivity of water. To address this in our study, larger water bodies were flattened to a consistent water level. Near-infrared LiDAR (which we used) does not work as well in mapping water bodies, but green-wavelength LiDAR has been shown to be a powerful tool for mapping the ground surface beneath small water-filled thermokarst features (Collin et al., 2010). LiDAR also is a powerful tool for investigating the relationships between geomorphologic features and landscape processes, particularly where landscape change can be captured by repeat imagery collection. Furthermore, depending on the season, size of smaller scale features, and presence or absence of snow melt or rainfall in these water features, it could be even more challenging to use LiDAR to estimate areas of landscape change.

Although vegetation and topographic characteristics have often been used to infer the presence or absence of shallow permafrost (i.e., 1-2 m), they are less useful for assessing the distribution of deep (i.e., >5-10 m below the ground surface) permafrost. Further, the complex transition boundary morphology between thawed and frozen material reduces our ability to accurately predict how and where permafrost will respond to climate warming or land surface disturbance. This is of particular concern for efforts to predict the fate of carbon stored in permafrost and to predict the spatial and

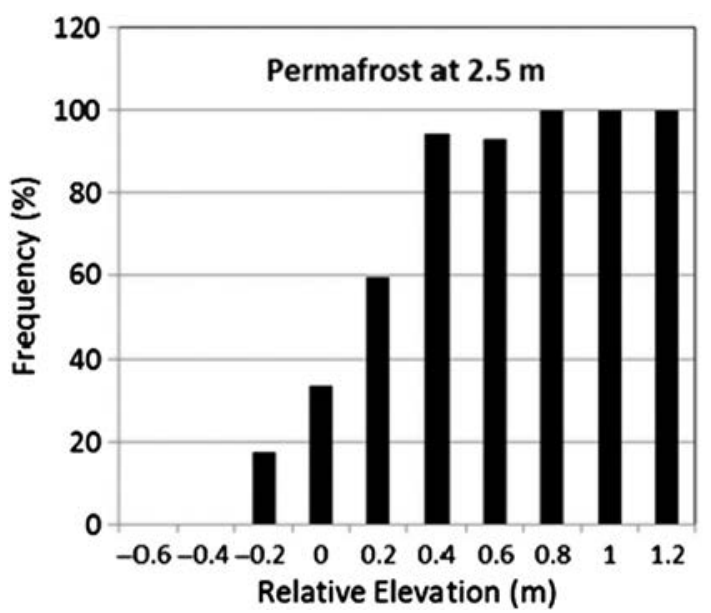

Figure 10. The relationship between the percentage of permafrost extent and the relative elevation. 
temporal ecosystem or hydrologic processes that will respond to changes in permafrost extent (Turetsky et al., 2002; McGuire et al., 2009; Euskirchen et al., 2010; Jorgenson et al., 2013; Schuur et al., 2013). Regional carbon assessment studies using aerial imagery of easily identifiable terrain features typically associated with thawed zones (like bogs, fens, or ponds) to map the percent of frozen ground in discontinuous permafrost lowlands would not account for the complex transitions between frozen and thawed material. The lack of consistent vertical transition zones between frozen and thawed material would lead to the underestimation of permafrost extent in the subsurface. Our results suggest that the processes affecting subsurface permafrost distribution are not simple or uniform across the landscape.

\section{CONCLUSIONS}

In an area of rapidly degrading permafrost ERT proved to be a reliable method for mapping surface permafrost occurrence and the complex distribution of permafrost or unfrozen soil (taliks) at depths up to $30 \mathrm{~m}$. The successful application of ERT is due to the large difference in resistivity values for frozen and unfrozen soil. Along five approximately 200- to 300-m transects established across a chronosequence of fire scars on the Tanana Flats in interior Alaska, we found a moderately high agreement $(80 \%)$ between thaw probing and ERT in mapping the location of the near-surface top of permafrost (upper $2.5 \mathrm{~m}$ ). The lateral margins of thawing collapse-scar bogs and fens had complex irregularities; however, and permafrost distribution was more variable with depth as interpreted from the ERT. Some thawed zones had gently sloping walls, some were lacking permafrost in the upper approximately $5 \mathrm{~m}$ but had permafrost at depth, and some areas had small horizontal lenses of permafrost at depth. We found strong relationships between vegetation type, topography measured with dGPS and LiDAR, and permafrost extent in this relatively flat, ice-rich, lowland landscape. Permafrost was nearly always present under forest types, had highly variable thaw depths and occasional thin closed taliks in recently burned areas, and it was nearly always absent in old collapse-scar bogs. In young collapse-scar bogs or actively collapsing margins in older bogs, the ERT data indicated that permafrost was often present at depth. Permafrost was also strongly related to topography, nearly always being present in areas that were $>0.2 \mathrm{~m}$ higher than the bogs and fens, and it was usually absent in the lower lying bogs. These relationships indicate that remote sensing of vegetation characteristics and LiDAR can be useful for monitoring the surficial and seasonal thaw-depth response of permafrost to fire, human disturbance, or climate warming. However, the complexity of permafrost distribution at greater depths and the highly irregular nature of the boundaries along the thawing margins indicated by ERT affect the reliability of using surface characteristics to assess permafrost changes. ERT is expensive to collect, and this limits its utility for applications over large spatial areas. Together, the combination of broad mapping of surface characteristics through remote sensing and limited ERT profiling can be used to better evaluate permafrost distribution near the surface and deeper into subsurface soils.

\section{ACKNOWLEDGMENTS}

This research was funded by the Department of Defense's Strategic Environmental Research and Development Program (project no. RC-2110), the U.S. Army Corps of Engineers Engineer Re- search and Development Center's Center Directed Research Program, the U.S. Army Engineer Research and Development Center's Basic Research Program, and the Changing Arctic Ecosystems Initiative of the U.S. Geological Survey's Ecosystem Mission Area through the Alaska Cooperative Fish and Wildlife Research Unit and the Institute of Arctic Biology at the University of Alaska Fairbanks (Brown). S. Newman oversaw the LiDAR data acquisition. D. Rees helped with helicopter logistics. We thank A. Barker, M. Berkeland, K. Bjella, H. Genet, T. Gatesman, A. Gelvin, S. Hayes, M. Jones, K. Jorgenson, M. Lara, H. Lotvonen, K. Nicolato, and A. Wagner for their help with field measurements. Two anonymous reviewers provided constructive comments that strengthened an earlier version of the manuscript.

\section{REFERENCES}

Abermann, J., A. Fischer, A. Lambrecht, and T. Geist, 2009, Multi-temporal airborne LIDAR-DEMs for glacier and permafrost mapping and monitoring: The Cryosphere Discussions, 3, 383-414, doi: 10.5194/tcd-3-3832009

Allison, S. D., and K. K. Treseder, 2011, Climate change feedbacks to microbial decomposition in boreal soils: Fungal Ecology, 4, 362-374, doi: 10.1016/j.funeco.2011.01.003.

Balshi, M. S., A. D. McGuire, P. Duffy, M. Flannigan, D. W. Kicklighter, and J. Melillo, 2009, Vulnerability of carbon storage in North American boreal forests to wildfires during the 21st century: Global Change Biology, 15, 1491-1510, doi: 10.1111/j.1365-2486.2009.01877.x.

Barrett, K., A. McGuire, E. Hoy, and E. Kasischke, 2011, Potential shifts in dominant forest cover in interior Alaska driven by variations in fire severity: Ecological Applications, 21, 2380-2396, doi: 10.1890/10-0896.1.

Brabets, T. P., B. Wang, and R. H. Meade, 2000, Environmental and hydrologic overview of the Yukon River Basin, Alaska and Canada: U.S. Department of the Interior, U.S. Geological Survey, Report 99-4204.

Brown, D., M. T. Jorgenson, T. A. Douglas, V. Romanovsky, K. Kielland, C. Hiemstra, E. Euskirchen, and R. W. Ruess, 2015, Interactive effects of wildfire and climate on permafrost degradation in Alaskan lowland forests: Journal of Geophysical Research: Biogeosciences, 120, 1619-1637, doi: 10.1002/2015JG003033.

Chacho, E., S. Arcone, and A. Delaney, 1995, Blair Lakes target facility permafrost and groundwater study: U.S. Army Cold Regions Research and Engineering Laboratory, Technical report, 30.

Chapin, F. S., S. F. Trainor, O. Huntington, A. L. Lovecraft, E. Zavaleta, D. C. Natcher, A. D. McGuire, J. L. Nelson, L. Ray, M. Calef, N. Fresco, H. Huntington, T. S. Rupp, L. DeWilde, and R. L. Naylor, 2008, Increasing wildfire in Alaska's boreal forest: Pathways to potential solutions of a wicked problem: Bioscience, 58, 531-540, doi: 10.1641/B580609.

Chapman, W. L., and J. E. Walsh, 2007, Simulations of Arctic temperature and pressure by global coupled models: Journal of Climate, 20, 609-632, doi: $10.1175 /$ JCLI4026.1.

Collin, A., B. Long, and P. Archambault, 2010, Salt-marsh characterization, zonation assessment and mapping through a dual-wavelength LiDAR: Remote Sensing of Environment, 114, 520-530, doi: 10.1016/j.rse .2009.10.011.

Davidson, E. A., and I. A. Janssens, 2006, Temperature sensitivity of soil carbon decomposition and feedbacks to climate change: Nature, 440 , 165-173, doi: 10.1038/nature04514.

Douglas, T. A., J. D. Blum, L. Guo, K. Keller, and J. D. Gleason, 2013, Hydrogeochemistry of seasonal flow regimes in the Chena River: A subarctic watershed draining discontinuous permafrost in interior Alaska (USA): Chemical Geology, 335, 48-62, doi: 10.1016/j.chemgeo.2012 .10 .045 .

Douglas, T. A., D. Fortier, Y. I. Shur, M. Z. Kanevskiy, L. Guo, Y. Cai, and M. Bray, 2011, Geomorphic and geochemical characteristics of thermokarst-cave ice in the CRREL Permafrost Tunnel, Alaska: Permafrost and Periglacial Processes, 22, 120-128, doi: 10.1002/ppp.709.

Douglas, T. A., M. C. Jones, C. A. Hiemstra, and J. Arnold, 2014, Sources and sinks of carbon in boreal ecosystems of interior Alaska: Current and future perspectives for land managers: Elementa: Science of the Anthropocene, 2, 39.

Douglas, T. A., M. T. Jorgenson, M. Z. Kanevskiy, V. E. Romanovsky, Y. Shur, and K. Yoshikawa, 2008, Permafrost dynamics at the Fairbanks Permafrost Experimental Station near Fairbanks, Alaska, in D. Kane, and K. Hinkle, eds., Proceedings of the Ninth International Conference on Permafrost: University of Alaska Fairbanks, 373-378.

Duffy, P. A., J. E. Walsh, J. M. Graham, D. H. Mann, and T. S. Rupp, 2005, Impacts of large-scale atmospheric-ocean variability on Alaskan fire sea- 
son severity: Ecological Applications, 15, 1317-1330, doi: 10.1890/040739.

Euskirchen, E., A. McGuire, F. S. Chapin, and T. Rupp, 2010, The changing effects of Alaska's boreal forests on the climate system: Canadian Journal of Forest Research, 40, 1336-1346, doi: 10.1139/X09-209.

Fortier, R., A.-M. LeBlanc, M. Allard, S. Buteau, and F. Calmels, 2008, Internal structure and conditions of permafrost mounds at Umiujaq in $\mathrm{Nu}-$ navik, Canada, inferred from field investigation and electrical resistivity tomography: Canadian Journal of Earth Sciences, 45, 367-387, doi: 10 .1139/E08-004

Frey, K. E., and L. C. Smith, 2005, Amplified carbon release from vast West Siberian peatlands by 2100: Geophysical Research Letters, 32, L09401, doi: $10.1029 / 2004$ GL022025.

Harada, K., and K. Yoshikawa, 1996, Permafrost age and thickness near Adventfjorden, Spitsbergen: Polar Geography, 20, 267-281, doi: 10 $.1080 / 10889379609377607$.

Hauck, C., 2013, New concepts in geophysical surveying and data interpretation for permafrost terrain: Permafrost and Periglacial Processes, 24, 131-137, doi: $10.1002 /$ ppp.1774.

Hauck, C., and C. Kneisel, 2008, Applied geophysics in periglacial environments: Cambridge University Press.

Hoekstra, P., and D. McNeill, 1973, Electromagnetic probing of permafrost, in Troy Péwé, and J. Ross Mackay, eds., Proceedings of Permafrost: North American contribution to the Second International Conference, National Academy of Sciences, National Research Council, 517-526.

Hubbard, S. S., C. Gangodagamage, B. Dafflon, H. Wainwright, J. Peterson, A. Gusmeroli, C. Ulrich, Y. Wu, C. Wilson, J. Rowland, C. Tweedie, and S. D. Wullscheleger, 2013, Quantifying and relating land-surface and subsurface variability in permafrost environments using LiDAR and surface geophysical data sets: Hydrogeology Journal, 21, 149-169, doi: 10.1007/ s10040-012-0939-y.

Johnson, K. D., J. Harden, A. D. McGuire, N. B. Bliss, J. G. Bockheim, M. Clark, T. Nettleton-Hollingsworth, M.T. Jorgenson, E. Kane, M. Mack, J. O'Donnell, C.-L. Ping, E.A.G. Schuur, M.R. Turetsky, and D.W. Valentine, K. D., J. Harden, A. D. McGuire, N. B. Bliss, J. G. Bockheim, T. Nettleton-Hollingsworth, M. T. Jorgenson, E. Kane, M. Mack, J. O'Donnell, C.-L. Ping, E. A. G. Schuur, M. R. Turetsky, and D.W. Valentine, 2011, Soil carbon distribution in Alaska in relation to soil-forming factors: Geoderma, 16, 771-784, doi: 10.1016/j.geoderma.2011.10.006.

Jones, B. M., J. M. Stoker, A. E. Gibbs, G. Grosse, V. E. Romanovsky, T. A. Douglas, N. E. M. Kinsman, and B. M. Richmond, 2013, Quantifying landscape change in an arctic coastal lowland using repeat airborne $\mathrm{Li}$ DAR: Environmental Research Letters, 8, 045025, doi: 10.1088/17489326/8/4/045025.

Jorgenson, M. T., J. Harden, M. Kanevskiy, J. O'Donnell, K. Wickland, S. Ewing, K. Manies, Q. Zhuang, Y. Shur, and R. Striegl, 2013, Reorganization of vegetation, hydrology and soil carbon after permafrost degradation across heterogeneous boreal landscapes: Environmental Research Letters, 8, 035017, doi: 10.1088/1748-9326/8/3/035017.

Jorgenson, M. T., M. Kanevskiy, Y. Shur, T. Osterkamp, D. Fortier, T. Cater, and P. Miller, 2012, Thermokarst lake and Shore Fen development in boreal Alaska, in K. Hinkel, ed., Proceedings of the Tenth International Conference on Permafrost, University of Alaska Fairbanks179-184.

Jorgenson, M. T., and T. Osterkamp, 2005, Response of boreal ecosystems to varying modes of permafrost degradation: Canadian Journal of Forest Research, 35, 2100-2111, doi: 10.1139/x05-153.

Jorgenson, M. T., C. H. Racine, J. C. Walters, and T. E. Osterkamp, 2001, Permafrost degradation and ecological changes associated with a warming climate in central Alaska: Climatic Change, 48, 551-579, doi: 10.1023/A: 1005667424292.

Jorgenson, M. T., V. Romanovsky, J. Harden, Y. Shur, J. O’Donnell, E. A. G. Schuur, M. Kanevskiy, and S. Marchenko, 2010, Resilience and vulnerability of permafrost to climate change: Canadian Journal of Forest Research, 40, 1219-1236, doi: 10.1139/X10-060.

Jorgenson, M. T., J. E. Roth, M. Raynolds, M. D. Smith, W. Lentz, A. L. Zusi-Cobb, and C. H. Racine, 1999, An ecological land survey for Fort Wainwright, Alaska: U.S. Army Cold Regions Research and Engineering Laboratory, CRREL Report 99-9, 83

Jorgenson, M. T., K. Yoshikawa, M. Kanveskiy, Y. L. Shur, V. Romanovsky, S. Marchenko, G. Grosse, J. Brown, and B. Jones, 2008, Permafrost characteristics of Alaska, in Kane, D. L., and K. M. Hinkel, eds., Proceedings of the Ninth International Conference on Permafrost: University of Alaska, 121-122.

Kasischke, E. S., N. H. French, K. P. O’Neill, D. D. Richter, L. L. BourgeauChavez, and P. A. Harrell, 2000a, Influence of fire on long-term patterns of forest succession in Alaskan boreal forests, in Kasischke, E. S., and B. J. Stocks, eds., Fire, climate change, and carbon cycling in the boreal forest: Springer, 214-235.

Kasischke, E. S., K. P. O'Neill, N. H. French, and L. L. Bourgeau-Chavez, $2000 \mathrm{~b}$, Controls on patterns of biomass burning in Alaskan boreal forests, in Kasischke, E. S., and B. J. Stocks, eds., Fire, climate change, and carbon cycling in the boreal forest: Springer, 173-196.
Kasischke, E. S., and M. R. Turetsky, 2006, Recent changes in the fire regime across the North American boreal region: Spatial and temporal patterns of burning across Canada and Alaska: Geophysical Research Letters, 33, L09703, doi: 10.1029/2006GL025677.

Kasischke, E. S., D. L. Verbyla, T. S. Rupp, A. D. McGuire, K. A. Murphy, R. Jandt, J. L. Barnes, E. E. Hoy, P. A. duffy, M. Calef, and M. R. Turetsky, 2010, Alaska's changing fire regime-implications for the vulnerability of its boreal forests: Canadian Journal of Forest Research, 40, 1313-1324, doi: 10.1139/X10-098.

Kneisel, C., 2006, Assessment of subsurface lithology in mountain environments using 2D resistivity imaging: Geomorphology, 80, 32-44, doi: 10 .1016/j.geomorph.2005.09.012.

Kneisel, C., A. Emmert, and J. Kästl, 2014, Application of 3D electrical resistivity imaging for mapping frozen ground conditions exemplified by three case studies: Geomorphology, 210, 71-82, doi: 10.1016/j geomorph.2013.12.022.

Koven, C., D. Ringeval, B. Friedlingstein, P. Ciais, P. Cadule, D. Khvorostyanov, G. Krinner, and C. Tarnocai, 2011, Permafrost carbon-climate feedbacks accelerate global warming: Proceedings of the National Academy of the USA, 108, 14769-14774, doi: 10.1073/pnas.1103910108.

Lawson, D. E., J. C. Strasser, J. D. Strasser, S. A. Arcone, A. J. Delaney, and C. Williams, 1996, Geological and geophysical investigations of the hydrogeology of Fort Wainwright, Alaska. Part I: Canol Road area: U.S Army Cold Regions Research and Engineering Laboratory, CRREL Report 96-4.

Lewkowicz, A. G., B. Etzelmüller, and S. L. Smith, 2011, Characteristics of discontinuous permafrost based on ground temperature measurements and electrical resistivity tomography, southern Yukon, Canada: Permafrost and Periglacial Processes, 22, 320-342, doi: 10.1002/ppp.703.

Liston, G. E., and C. A. Hiemstra, 2011, The changing cryosphere: Pan-Arctic snow trends (1979-2009): Journal of Climate, 24, 5691-5712, doi: 10 $.1175 / J C L I-D-11-00081.1$.

Liu, L., K. Schaefer, T. Zhang, and J. Wahr, 2012, Estimating 1992-2000 average active layer thickness on the Alaskan North Slope from remotely sensed surface subsidence: Journal of Geophysical Research: Earth Surface, 117, F01005, doi: 10.1029/2011JF002041.

Loke, M. H., I. Acworth, and T. Dahlin, 2003, A comparison of smooth and blocky inversion methods in 2D electrical imaging surveys: Exploration Geophysics, 34, 182-187, doi: 10.1071/EG03182.

Loke, M. H., and R. D. Barker, 1996, Rapid least-squares inversion of apparent resistivity pseudosections by a quasi-Newton method: Geophysical Prospecting, 44, 131-152, doi: 10.1111/j.1365-2478.1996.tb00142.x.

Mann, D., C. Fastie, E. Rowland, and N. Bigelow, 1995, Spruce succession, disturbance, and geomorphology on the Tanana River floodplain, Alaska: Ecoscience, 2, 184-199.

Marchenko, S., V. Romanovsky, and G. Tipenko, 2008, Numerical modeling of spatial permafrost dynamics in Alaska, in D. L. Kane, and K. M. Hinkel, eds., Proceedings of the Ninth International Conference on Permafrost: University of Alaska Fairbanks, 1125-1130.

Marsh, P., M. Russell, S. Pohl, H. Haywood, and C. Onclin, 2009, Changes in thaw lake drainage in the western Canadian Arctic from 1950 to 2000: Hydrological Processes, 23, 145-158, doi: 10.1002/hyp.7179.

McClymont, A. F., M. Hayashi, L. R. Bentley, and B. S. Christensen, 2013, Geophysical imaging and thermal modeling of subsurface morphology and thaw evolution of discontinuous permafrost: Journal of Geophysical Research: Earth Surface, 118, 1826-1837, doi: 10.1002/jgrf .20114 .

McGuire, A. D., L. G. Anderson, T. R. Christensen, S. Dallimore, L. Guo, D. Hayes, M. Heimann, T. D. Lorenson, R. W. Macdonald, and N. Roulet, 2009, Sensitivity of the carbon cycle in the Arctic to climate change: Ecological Monographs, 79, 523-555, doi: 10.1890/08-2025.1.

Minsley, B. J., J. D. Abraham, B. D. Smith, J. C. Cannia, C. I. Voss, M. T. Jorgenson, M. A. Walvoord, B. K. Wylie, L. Anderson, B. Ball, M. Deszcz-Pan, T. P. Wellman, and T. A. Ager, 2012, Airborne electromagnetic imaging of discontinuous permafrost: Geophysical Research Letters, 39, L02503, doi: 10.1029/2011GL050079.

Myers-Smith, I., J. Harden, M. Wilmking, C. Fuller, A. D. McGuire, and F. S. Chapin, 2008, Wetland succession in a permafrost collapse: Interactions between fire and thermokarst: Biogeosciences, 5, 1273-1286, doi: $10.5194 / \mathrm{bg}-5-1273-2008$.

Nossov, D. R., M. T. Jorgenson, K. Kielland, and M. Z. Kanevskiy, 2013, Edaphic and microclimatic controls over permafrost response to fire in interior Alaska: Environmental Research Letters, 8, 035013, doi: 10 .1088/1748-9326/8/3/035013.

O’Donnell, J. A., M. T. Jorgenson, J. W. Harden, A. D. McGuire, M. Z. Kanevskiy, and K. P. Wickland, 2012, The effects of permafrost thaw on soil hydrologic, thermal, and carbon dynamics in an Alaskan peatland: Ecosystems, 15, 213-229, doi: 10.1007/s10021-011-9504-0.

O'Neill, K. P., E. S. Kasischke, and D. D. Richter, 2002, Environmental controls on soil $\mathrm{CO}_{2}$ flux following fire in black spruce, white spruce, and aspen stands of interior Alaska: Canadian Journal of Forest Research, 32, 1525-1541, doi: 10.1139/x02-077. 
O'Neill, K. P. E. S. Kasischke, and D. D. Richter, 2003, Seasonal and decadal patterns of soil carbon uptake and emission along an age sequence of burned black spruce stands in interior Alaska: Journal of Geophysical Research: Atmospheres, 108, 8155, doi: 10.1029/2001JD000443.

Osterkamp, T., 2007, Characteristics of the recent warming of permafrost in Alaska: Journal of Geophysical Research, 112, F02S02, doi: 10.1029/ $2006 J$ J 000578.

Osterkamp, T., M. Jorgenson, E. Schuur, Y. Shur, M. Kanevskiy, J. G. Vogel, and V. E. Tumskoy, 2009, Physical and ecological changes associated with warming permafrost and thermokarst in interior Alaska: Permafrost and Periglacial Processes, 20, 235-256, doi: 10.1002/ppp.656.

Osterkamp, T. E., R. W. Jurick, G. A. Gislason, and S.-I. Akasofu, 1980, Electrical resistivity measurements in permafrost terrain at the Engineer Creek road cut, Fairbanks, Alaska: Cold Regions Science and Technology, 3, 277-286, doi: 10.1016/0165-232X(80)90034-8.

Osterkamp, T., and V. Romanovsky, 1999, Evidence for warming and thawing of discontinuous permafrost in Alaska: Permafrost and Periglacial Processes, 10, 17-37, doi: 10.1002/(SICI)1099-1530(199901/03)10: $1<17::$ AID-PPP303>3.0.CO;2-4.

Osterkamp, T., L. Viereck, Y. Shur, M. Jorgenson, C. Racine, A. Doyle, and R. D. Boone, 2000, Observations of thermokarst and its impact on boreal forests in Alaska, USA: Arctic, Antarctic, and Alpine Research, 32, 303315, doi: $10.2307 / 1552529$.

Panda, S. K., A. Prakash, M. T. Jorgenson, and D. N. Solie, 2012, Nearsurface permafrost distribution mapping using logistic regression and remote sensing in interior Alaska: GIScience \& Remote Sensing, 49, 346363 , doi: $10.2747 / 1548-1603.49 .3 .346$.

Pastick, N. J., M. T. Jorgenons, B. K. Wylie, J. R. Rose, M. Rigge, and M. A. Walvoord, 2014, Spatial variability and landscape controls of near-surface permafrost within the Alaskan Yukon River Basin: Journal of Geophysical Research: Biogeosciences, 119, 1244-1265, doi: 10.1002/2013JG002594.

Potter, C., 2004, Predicting climate change effects on vegetation, soil thermal dynamics, and carbon cycling in ecosystems of interior Alaska: Ecological Model, 175, 1-24, doi: 10.1016/j.ecolmodel.2003.05.004.

Racine, C. H., M. T. Jorgenson, and J. C. Walters, 1998. Thermokarst vegetation in lowland birch forests on the Tanana Flats, interior Alaska, USA, in A. G. Lewkowicz, and M. Allard, eds., Proceedings of the Seventh International Conference on Permafrost: Universite Laval, Collection Nordicana, 927-933.

Racine, C. H., and J. C. Walters, 1994, Groundwater-discharge fens in the Tanana Lowlands, interior Alaska, USA: Arctic and Alpine Research, 26, 418-426, doi: 10.2307/1551804.

Schuur, E. A. G., B. W. Abbott, W. B. Bowden, V. Brovkin, P. Camill, J. G. Canadell, J. P. Chanton, F. S. Chapin, III, T. R. Christensen, P. Ciais, B. T. Crosby, C. I. Czimczik, G. Grosse, J. Harden, D. J. Hugelius, G. Jastrow, J. B. Jones, T. Kleinen, C. D. Koven, G. Krinner, P. Kuhry, D. M. Lawrence, A. D. McGuire, S. M. Natali, J. A. O’Donnell, C. L. Ping, W. J. Riley, A. Rinke, V. E. Romanovsky, A. B. K. Sannel, C. Schädel, K. Schaefer, J. Sky, Z. M. Subin, C. Tarnocai, M. R. Turetsky, M. P. Waldrop, K. M Walter Anthony, K. P.. Wickland, C. J. Wilson, and S. A. Zimov, 2013, Expert assessment of vulnerability of permafrost carbon to climate change: Climatic Change, 119, 359-374, doi: 10.1007/s10584013-0730-7.

Shiklomanov, N. I., D. A. Streletskiy, J. D. Little, and F. E. Nelson, 2013 , Isotropic thaw subsidence in undisturbed permafrost landscapes: Geophysical Research Letters, 40, 6356-6361, doi: 10.1002/2013GL058295.

Shur, Y. L., and M. T. Jorgenson, 2007, Patterns of permafrost formation and degradation in relation to climate and ecosystems: Permafrost and Periglacial Processes, 18, 7-19, doi: 10.1002/ppp.582.

Sierra, C., M. Harmon, E. Thomann, S. Perakis, and H. Loescher, 2011, Amplification and dampening of soil respiration by changes in temper- ature variability: Biogeosciences, 8, 951-961, doi: 10.5194/bg-8-9512011.

Stevens, C. W., and S. A. Wolfe, 2012, High-resolution mapping of wet terrain within discontinuous permafrost using LiDAR intensity: Permafrost and Periglacial Processes, 23, 334-341, doi: 10.1002/ppp.1752.

Tarnocai, C., and I. Campbell, 2002, Soils of the polar regions, in Lal, R., ed., Encyclopaedia of soil science: Marcel Dekker, 1018-1021.

Turetsky, M. R., R. K. Wieder, and D. H. Vitt, 2002, Boreal peatland C fluxes under varying permafrost regimes: Soil Biology and Biochemistry, 34, 907-912, doi: 10.1016/S0038-0717(02)00022-6.

Viereck, L. A., 1973, Ecological effects of river flooding and forest fires on permafrost in the taiga of Alaska, in Permafrost-The North American Contribution to the Second International Conference., 60-67.

Walker, M. D., C. H. Wahren, R. D. Hollister, G. H. Henry, L. E. Ahlquist, J. M. Alatalo, M. S. Bret-Harte, M. P. Calef, T. V. Callaghan, A. B. Carroll, H. E. Epstein, I. Jónsdóttir, U. Klein, B. Magnūsson, U. Molau, S. F Oberbauer, S. P. Rewa, C. H. Robinson, G. R. Shaver, K. N. Suding, C. C. Thompson, A. Tolvanen, O. Totland, P. L. Turner, C. E. Tweedie, P. J. Webber, and P. A. Wookey, 2006, Plant community responses to experimental warming across the tundra biome: Proceedings of the National Academy of Sciences of the USA, 103, 1342-1346, doi: 10.1073/pnas .0503198103 .

Walters, J. C., C. H. Racine, and M. T. Jorgenson, 1998, Characteristics of permafrost in the Tanana Flats, interior Alaska: in Lewkowicz, A. G., and M. Allard, eds., Proceedings of the Seventh International Conference on Permafrost, Collection Nordicana, 1109-1114.

Wendler, G., J. Conner, B. Moore, M. Shulski, and M. Stuefer, 2011, Climatology of Alaskan wildfires with special emphasis on the extreme year of 2004: Theoretical and Applied Climatology, 104, 459-472, doi: 10 1007/s00704-010-0357-9.

Wendler, G., and M. Shulski, 2009, A century of climate change for Fairbanks, Alaska: Arctic, 62, 295-300, doi: 10.14430/arctic149.

Wolken, J. M., T. N. Hollingsworth, T. S. Rupp, F. S. Chapin, III, S. F Trainor, T. M. Barrett, P. F. Sullivan, A. D. McGuire, E. S. Euskirchen, P. E. Hennon, E. A. Beever, J. S. Conn, L. K. Crone, D. V. D'Amore, N. Fresco, T. A. Hanley, K. Kielland, J. J. Kruse, T. Patterson, E. A. G. Schuur, D. L. Verbyla, and J. Yarie, 2011, Evidence and implications of recent and projected climate change in Alaska's forest ecosystems: Ecosphere, 2, 124

Wurtz, T. L., R. A. Ott, and J. C. Maisch, 2006, Timber harvest in interior Alaska: in Stuart Chapin, F., III, M. W. Osgood, K. van Cleve, L. A. Viereck, and D. L. Verbyla, eds., Alaska's changing boreal forest: Oxford University Press, 302-308.

Yoshikawa, K., and L. D. Hinzman, 2003, Shrinking thermokarst ponds and groundwater dynamics in discontinuous permafrost near Council, Alaska: Permafrost Periglacial Process, 14, 151-160, doi: 10.1002/ppp .451.

Yoshikawa, K., C. Leuschen, A. Ikeda, K. Harada, P. Gogineni, P. Hoekstra, L. Hinzman, Y. Sawada, and N. Matsuoka, 2006, Comparison of geophysical investigations for detection of massive ground ice (pingo ice): Journal of Geophysical Research: Planets, 111, E06S19, doi: 10.1029/ 2005 JE002573.

Zhuang, Q., A. D. McGuire, J. Melillo, J. Clein, R. Dargaville, D. W. Kicklighter, R. B. Dargaville, J. Myneni, V. E. Romanovsky, J. Harden, and J. E. Hobbie, 2003, Carbon cycling in extratropical terrestrial ecosystems of the Northern Hemisphere during the 20th century: A modeling analysis of the influences of soil thermal dynamics: Tellus B, 55, 751776, doi: $10.1034 /$ j.1600-0889.2003.00060.x

Zoltai, S., L. Morrissey, G. Livingston, and W. D. Groot, 1998, Effects of fires on carbon cycling in North American boreal peatlands: Environmental Review, 6, 13-24, doi: 10.1139/a98-002. 


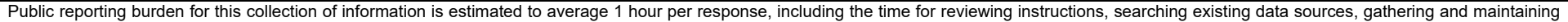

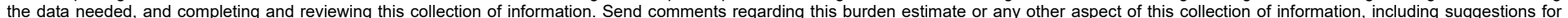

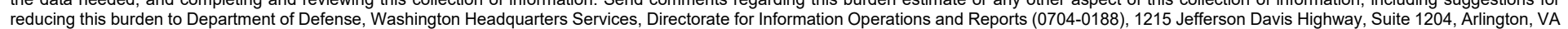

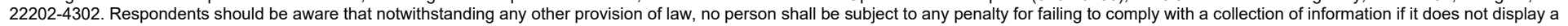
currently valid OMB control number. PLEASE DO NOT RETURN YOUR FORM TO THE ABOVE ADDRESS.
1. REPORT DATE (DD-MM-YYYY)
2. REPORT TYPE
July 2021
Final

4. TITLE AND SUBTITLE

Degrading permafrost mapped with electrical resistivity tomography, airborne imagery and LiDAR, and seasonal thaw measurements

3. DATES COVERED (From - To)

5a. CONTRACT NUMBER

5b. GRANT NUMBER

5c. PROGRAM ELEMENT NUMBER

6. AUTHOR(S)

Thomas A. Douglas, M. Torre Jorgenson, Dana R. N. Brown, Seth W. Campbell,

Christopher A. Hiemstra, Stephanie P. Saari, Kevin Bjella, and Anna K. Liljedahl

7. PERFORMING ORGANIZATION NAME(S) AND ADDRESS(ES)

See next page.

5d. PROJECT NUMBER

5e. TASK NUMBER

5f. WORK UNIT NUMBER

8. PERFORMING ORGANIZATION REPORT NUMBER

ERDC/CRREL MP-21-9

9. SPONSORING / MONITORING AGENCY NAME(S) AND ADDRESS(ES)

U.S. Army Corps of Engineers

Washington, DC 20314

10. SPONSOR/MONITOR'S ACRONYM(S)

USACE

11. SPONSOR/MONITOR'S REPORT NUMBER(S)

\section{DISTRIBUTION / AVAILABILITY STATEMENT}

Approved for public release; distribution is unlimited.

\section{SUPPLEMENTARY NOTES}

This article was originally published online in Geophysics on 17 December 2015. This project was funded by DoD SERDP Project

Number RC-2110, MIPR W74RDV10209988.

\section{ABSTRACT}

Accurate identification of the relationships between permafrost extent and landscape patterns helps develop airborne geophysical or remote sensing tools to map permafrost in remote locations or across large areas. These tools are particularly applicable in discontinuous permafrost where climate warming or disturbances such as human development or fire can lead to rapid permafrost degradation. We linked field-based geophysical, point-scale, and imagery surveying measurements to map permafrost at five fire scars on the Tanana Flats in central Alaska. Ground-based elevation surveys, seasonal thaw-depth profiles, and electrical resistivity tomography (ERT) measurements were combined with airborne imagery and light detection and ranging (LiDAR) to identify relationships between permafrost geomorphology and elapsed time since fire disturbance. ERT was a robust technique for mapping the presence or absence of permafrost because of the marked difference in resistivity values for frozen versus unfrozen material. There was no clear relationship between elapsed time since fire and permafrost extent at our sites. The transition zone boundaries between permafrost soils and unfrozen soils in the collapse-scar bogs at our sites had complex and unpredictable morphologies, suggesting attempts to quantify the presence or absence of permafrost using aerial measurements alone could lead to incomplete results. The results from our study indicated limitations in being able to apply airborne surveying measurements at the landscape scale toward accurately estimating permafrost extent.

\section{SUBJECT TERMS}

Permafrost; Climate changes; Alaska -- Tanana River Watershed; Optical radar; Aerial photogrammetry

\section{SECURITY CLASSIFICATION OF:}

\section{a. REPORT}

Unclassified

b. ABSTRACT

Unclassified

\section{c. THIS PAGE}

Unclassified
17. LIMITATION OF ABSTRACT

SAR
18. NUMBER OF PAGES

21 19a. NAME OF RESPONSIBLE PERSON 19b. TELEPHONE NUMBER (include area code) 
Cold Regions Research and Engineering Laboratory U.S. Army Engineer Research and Development Center Fort Wainwright, AK

Cold Regions Research and Engineering Laboratory U.S. Army Engineer Research and Development Center 72 Lyme Road

Hanover, NH 07355

Alaska Ecoscience

Fairbanks, AK

University of Alaska Fairbanks

Institute of Arctic Biology

Dept of Biology \& Wildlife

Fairbanks, AK

University of Alaska Fairbanks

Water \& Environmental Research Ctr

International Artic Research Center

Fairbanks, AK 